\title{
Multi-phased hypogene speleogenesis in a marginal horst structure of the Male Karpaty Mountains, Slovakia
}

\author{
Pavel Bella ${ }^{1,2^{*}}$, Pavel Bosák ${ }^{3}$, Petr Mikysek ${ }^{3,4}$, Juraj Littva ${ }^{2}$, Helena Hercman ${ }^{5}$, \\ and Jacek Pawlak ${ }^{5}$ \\ ${ }^{1}$ Department of Geography, Faculty of Education, Catholic University in Ružomberok, Hrabovská cesta 1, 03104 Ružomberok, Slovakia \\ ${ }^{2}$ State Nature Conservancy of the Slovak Republic, Slovak Caves Administration, Hodžova 11, 03101 Liptovský Mikuláš, Slovakia \\ ${ }^{3}$ Institute of Geology of the Czech Academy of Sciences, Rozvojová 269, 16500 Praha 6-Lysolaje, Czechia \\ ${ }^{4}$ Institute of Geological Sciences, Faculty of Science, Masaryk University, Kotlářská 267/2, 61137 Brno, Czechia \\ ${ }^{5}$ Institute of Geological Sciences, Polish Academy of Sciences, ul. Twarda 51/55, 00818 Warszawa, Poland
}

\begin{abstract}
The Plavecká jaskyňa Cave on the western fault edge of the Malé Karpaty Mountains (western Slovakia) is a result of multi-phased hypogene speleogenesis. It formed in fractured Triassic carbonates by waters ascending along the Vienna Basin Transform Fault between Malé Karpaty Mountains and Záhorská nížina Lowland (the north-eastern part of the Vienna Basin) and/or the $\mathrm{N}-\mathrm{S}$-trending faults that intersect it in the cave vicinity. Morphologically, the cave is featured by (1) phreatic chimneys, cupolas, ceiling pockets, enlarged fissures with spongework cavities, upward wall channels and upward oriented large scallops, (2) epiphreatic flat corrosion bedrock floors, feeding fissures and wall water-table notches, as well as (3) vadose vents, upward half tubes and shallow cupolas formed by condensation corrosion on the cooler overlying walls and ceilings. Initial fault-controlled phreatic morphologies of the cave formed due to the dissolution of limestones caused by ascending deep-seated water. The isotopic composition ( $O$ and $C)$ of the uppermost thin layer of limestone bedrock on the cave wall resulted from its interaction with hypogene water. Flat corrosion bedrock floors truncate fissure discharge feeders, on the edges with wall water-table notches, indicate rapid lateral corrosion by the sulfuric low-thermal waters. Four subhorizontal passages have been developed at former levels of the piezometric surface during water table stagnations corresponding with phases of erosion base level stabilization in relation to the landform evolution during the subsidence of the adjacent part of the Vienna Basin. The passage of the lowest evolution level is at about the same elevation as the recent springs of slightly warmer groundwater near the cave $\left(11.6\right.$ to $13.6^{\circ} \mathrm{C}$; about to $3^{\circ} \mathrm{C}$ warmer than the regional mean-annual temperature). In addition to morphological indicators (flat corrosion floors and associated wall water-table notches), the sulfuric low-temperature acid speleogenetical phases of the Plavecká jaskyňa are indicated by the presence of gypsum in association with hydrated kaolinite, illite, clinochlore and montmorillonite (XRD) in rare deposits. Subaerial calcite popcorn rims were also precipitated due to $\mathrm{H}_{2} \mathrm{O}$ evaporation and $\mathrm{CO}_{2}$ degassing from condensation water at the edges of feeding fissures that were still active as thermal vents when the water table was dropped. Hydrogen sulfide involved in the sulfuric acid speleogenesis was probably derived from hydrocarbon reservoirs of adjacent Vienna Basin. Features similar to those detected in the Plavecká jaskyňa were identified also in some other caves of the Plavecký Karst (e.g., Plavecká priepast' Shaft, Pec Cave).
\end{abstract}

Keywords: $\quad$ hypogene speleogenesis, ascending water, sulfuric acid speleogenesis, cave level, Plavecký Karst, Western Carpathians

Received 9 April 2019; Revised 7 August 2019; Accepted 13 August 2019

Citation: Bella P., Bosák P., Mikysek P., Littva J., Hercman H. and Pawlak J., 2019. Multi-phased hypogene speleogenesis in a marginal horst structure of the Malé Karpaty Mountains, Slovakia. International Journal of Speleology, 48 (2), 203-220. Tampa, FL (USA) ISSN 03926672 https://doi.org/10.5038/1827-806X.48.2.2265

\section{INTRODUCTION}

Plavecká jaskyňa Cave (western Slovakia) developed near the eastern fault limit of the Vienna Basin at the north-western margin of the Malé Karpaty Mountains. Its structural-geological and hydrogeological settings highly resemble the situation of Bad Deutsch
Altenburg sulfuric acid caves at the south-eastern edge of this basin in Austria (e.g., Plan et al., 2006, 2009; Pavuza \& Plan, 2008; De Waele et al., 2016; Spötl et al., 2017). The position along the marginal fault line between Malé Karpaty Mountains and the Vienna Basin (or the Záhorská nižina Lowland as its northeastern part) and special speleogens (like cupolas, 
chimneys, ceiling pockets, feeders and other associated solution forms) could indicate the speleogenesis of the Plavecká jaskyña by hypogene ascending waters, although direct evidence has been missing (Bella, 2010; Bella \& Bosák, 2012; Bella \& Gaál, 2012, 2017). The very similar situation exists also in $\mathrm{Na}$ Turoldu Cave in Southern Moravia, Czech Republic (Bosák et al., 1984; Bosák, 2013), which is located in the outer klippen belt of Western Carpathians at its fault contacts with the Carpathian Foredeep and Vienna Basin.

In older literature, the Plavecká jaskyña was described as a fissurebreakdown cave, formed by corrosion of limestones by meteoric water seeping along faults and bedding planes (Droppa, 1958, 1973; Tencer, 1991), or as a bedding-breakdown cave (Mitter, 1983). Hochmuth (2008) noticed that Plavecká jaskyña consists of paleokarst cavities originated in the stagnant water of unknown origin. Šmida (2010) described it as a phreatic cave in a complicated outflow zone with older subhorizontal passages and younger chimneys and he linked the origin of chimneys with repeated groundwater table oscillations.

Therefore, our research is focused more detail on the cave morphology and other indicators of the assumed ascending speleogenesis of this remarkable but scantily investigated cave.

\section{LOCATION AND GENERAL DATA}

The Plavecká jaskyňa (PLA) is situated on the north-western slope of Malé Karpaty (Lesser Carpathians) Mountains, north from the village of Plavecké Podhradie and north-west from Pohanská Hill (495 m a.s.1.), at the NNW foot of Plavecký hradný (Castle) vrch Hill (431 m a.s.1.; Figs. 1 and 2A). Orographically, Plavecký hradný vrch and Pohanská belong to the south-western part of Plavecké predhorie Foothills that is separated from the Biele hory (the main range of this part of Malé Karpaty named Pezinské Karpaty) by the Bukovská brázda Furrow. To the NW, the Plavecké predhorie is bordered by the Podmalokarpatská zníženina Depression, a geomorphological subunit of the Záhorská nížina Lowland/Vienna Basin.

The upper narrow discovery entrance is located at $236 \mathrm{~m}$ a.s.1. The surface opening of the artificial tunnel excavated into lower-lying cave passages and halls is at $221 \mathrm{~m}$ a.s.1. (Fig. 2B). The cave is $1,120 \mathrm{~m}$ long (Tencer, 2019) and $33 \mathrm{~m}$ deep (Šmida, 2010).

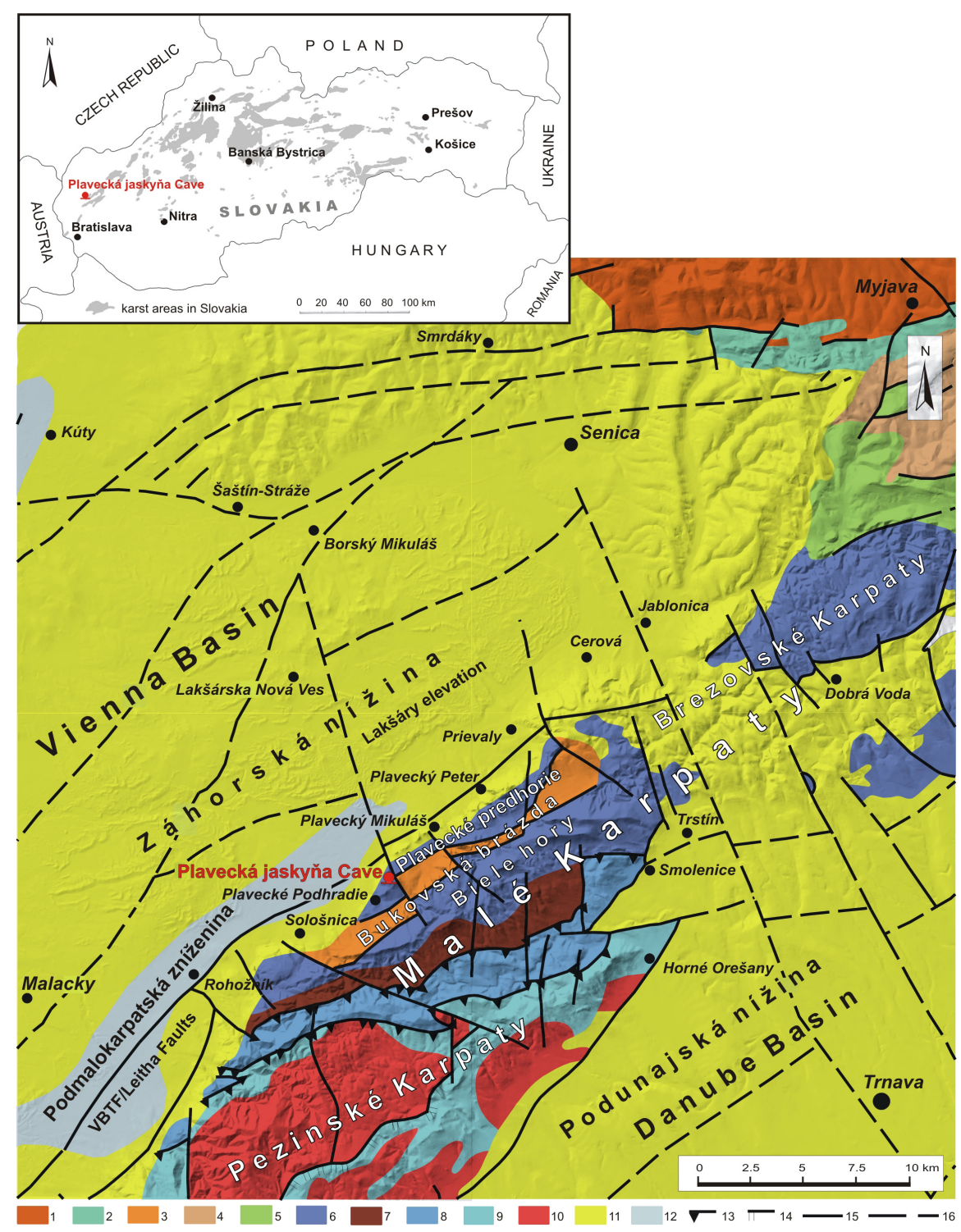

Fig. 1. Location of Plavecká jaskyňa and geological settings of its wider surroundings (iclastics; 2) Pieniny Klippen Belt, Mesozoic to Paleogene carbonates and siliciclastics. Group, Cretaceous carbonates and conglomerates. Hronic Unit: 6) Mesozoic carbonates; Unit: 9) sedimentary cover, Permian siliciclastics and Mesozoic carbonates; 10) core complex, Proterozoic(?) to Paleozoic crystalline rocks. Neogene: 11) marine to terrestrial siliciclastics. Quaternary: 12) fluvial to lacustrine siliciclastics. Tectonics: 13) primary nappe décollements; 14) secondary thrust lines; 15) faults; 16) supposed faults.
The PLA is one of the oldest known caves in the Malé Karpaty Mountains, being discovered at the end of the $18^{\text {th }}$ century and adapted to the public in the beginning of the $19^{\text {th }}$ century (Lalkovič, 2010). The first geomorphological research of the PLA was realized by A. Droppa in 1954.

\section{SETTINGS}

Geologically, the Male Karpaty are the westernmost core mountains of the Western Carpathians. They represent a NE-SW-trending horst structure dividing Neogene Vienna and Danube basins. Tatric crystalline basement of the Malé Karpaty Mountains is covered by Early Paleozoic-Mesozoic autochthonous sedimentary cover. The autochthon is overthrusted by nappe units of Fatricum and Hronicum, and in places also covered 


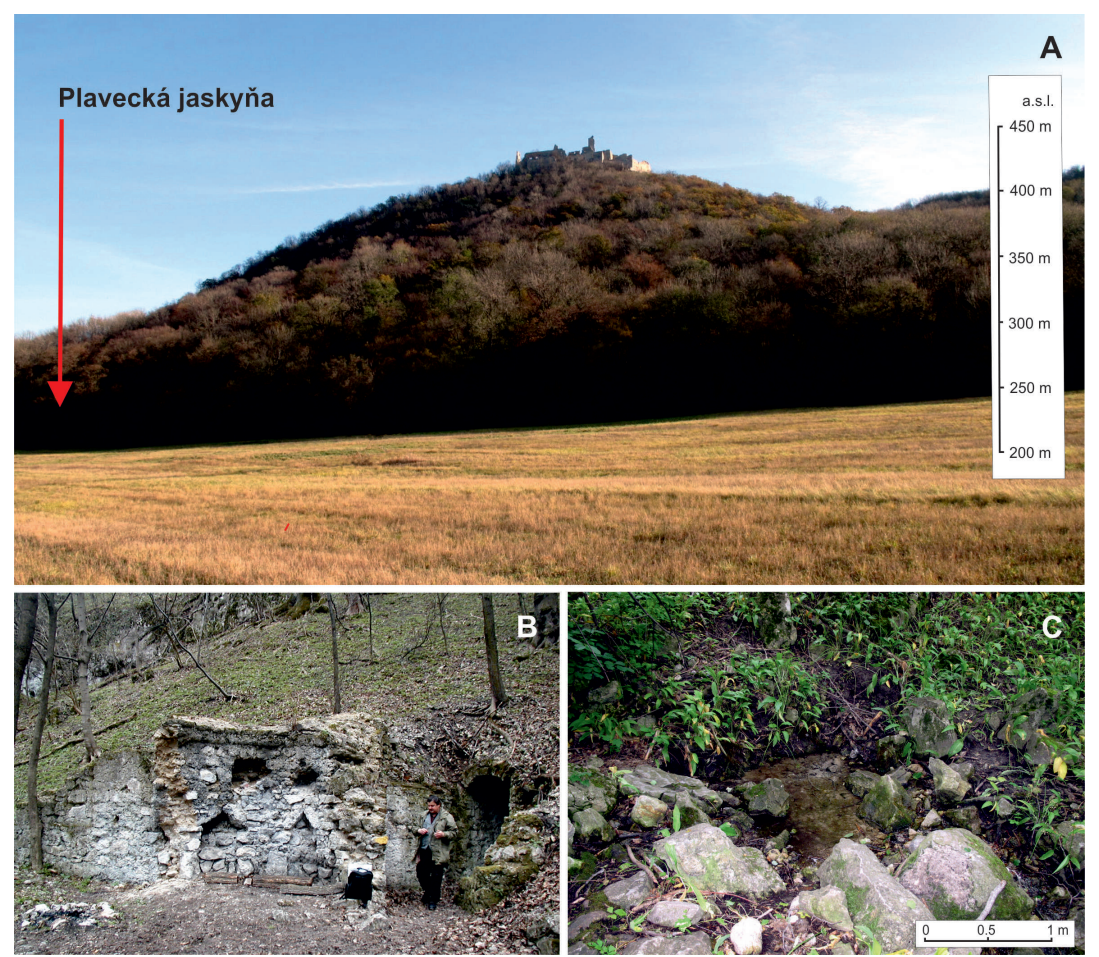

Fig. 2. A) Plavecký hradný vrch Hill; B) the surface opening of the artificial tunnel leading to the Plavecká jaskyňa, C - the main spring located $\sim 150 \mathrm{~m}$ south-west from the Plavecká jaskyňa (Photo: P. Bella).

by post-tectonic sediments (e.g., Mahel \& Cambel, 1972; Mahel, 1986, 1987; Plašienka et al., 1991; Polák et al., 2011, 2012).

The horst structure of the Male Karpaty is faultseparated from the adjacent Vienna Basin by a segment of large-scale fault extending into the area from the Eastern Alps (Decker et al., 2005; Beidinger $\&$ Decker, 2011). Various names are used for the main fault, as well as its segments (see Hók et al., 2018). For this paper, the term "Vienna Basin Transform Fault" (VBTF; used by Decker et al., 2005 and others) was chosen for the main fault, and the term "Leitha faults" (used by Marko \& Jureňa, 1999; Fordinál et al., 2012b and others) for its segment of VBTF in the area of interest.

The Vienna Basin (including the Záhorská nížina) represents a subsidence Miocene pull-apart basin (Royden, 1985; Fodor, 1995; Decker, 1996; Arzmüller et al., 2006 and others) with shallow tectonics in its northern part and deeper faults or full crustal extension in its central and southern ones (Lankreijer et al., 1995; Kováč et al., 1997; Kováč, 2000 and others). Later tectonic activity separated the Vienna Basin into a set of smaller partial depressions and elevations (Lankreijer et al., 1995; Arzmüller et al., 2006; Fordinál et al., 2012b; Lee \& Wagreich, 2017 and others; Fig. 1). The basin fill consists predominantly of Miocene, Pliocene, and Quaternary marine, lacustrine, and terrestrial sediments.

The Mesozoic carbonate host rocks of PLA crop out in the narrow ridge of Plavecké predhorie, stretching in the NE-SW direction, which is delimited from the adjacent depressions by outward-dipping faults. To the southeast, the elevation is separated from the main block of Malé Karpaty by the adjacent Buková brázda (Fig. 1), filled with shallow to deep marine siliciclastics of Paleogene age (Polák et al., 2011, 2012; Fordinál et al.,
$2012 \mathrm{a}, \mathrm{b})$. To the north-west, the elevation is bordered by the Podmalokarpatská zníženina (Fig. 1). Morphologically, it represents a longitudinal shallow negative morphostructure associated with the smaller graben or pull-apart sub-basins of the Vienna Basin. Ban̆acký \& Sabol (1973), Kováč (2000), Kováč et al. (2004), Arzmüller et al. (2006), Fordinál et al. (2012b) and some others relate the subsiding eastern edge of the Vienna Basin to the Zohor Plavecký Mikuláš Graben, while others with the pull-apart sub-basins of the Vienna Basin (Salcher et al., 2012). The Pliocene and Quaternary fill of the depression locally reaches significant thickness. The largest thickness of Quaternary sediments was detected in the Sološnica Sub-Basin at the contact with the western, tectonically fractured edge of Plavecký Karst including the PLA. Pliocene sediments are at least $20 \mathrm{~m}$ thick while the thickness of Quaternary sediments is more than $100 \mathrm{~m}$ in the PLA vicinity (Kullman, 1966, 1980; Vaškovská, 1971; Fordinál et al., 2012b and others).

The PLA is formed in carbonates of Triassic Wetterstein Formation (locally with lenses of carbonate breccias) of the Hronic Unit (see Polák et al., 2011, 2012; Fordinál et al., 2012a, b), mostly parallel to the fault-controlled slope (Liška, 1976). These carbonates are massive, bedding-planes or bedding-plane fractures are not visible. The cave origin was mostly controlled by NNE-SSW- and NNWSSE-trending fissures, joints, and faults (Briestenský $\&$ Stemberk, 2008) with measured horizontal strikeslip movements on some of them (Briestensky et al., 2010).

Allochthonous sediments are missing in the cave. Dripstones, flowstones, and moonmilk are developed in several places, mostly in inclined upper cave parts. Guano, often weathered, covers walls and floors in places, as the PLA represents an important hibernation bat roost (Rhinolophus hipposideros, Myotis myotis, Barbastella barbastellus and Miniopterus schreibersii; Lehotská \& Lehotský, 2010 and others).

The PLA and nearby Plavecká priepast Shaft (see Butaš, 2003) belong to the warmest caves in Slovakia with an air temperature of 11 to $12.8^{\circ} \mathrm{C}$. Lake water with $\sim 13^{\circ} \mathrm{C}$ at the bottom of the Plavecká priepast causes air temperature increase up to $12.7-12.8^{\circ} \mathrm{C}$ (Košel, 2005). The lake with slightly warmer water occasionally occurs also in the lowest place of the PLA, in its southwestern part (Hubek \& Magdolen, 2008; Šmída, 2010) influencing the air temperature there (Briestenský $\&$ Stemberk, 2008). However, groundwater level has dropped in the last years probably due to long-lasting droughts. Recently discovered passages and two $10 \mathrm{~m}$ deep shafts (October 2018, with a total length more than $150 \mathrm{~m}$ ) lead downwards from the upper part of the cave (Herz \& Velšmid, 2018; Grúz, 2019). They are flooded with stagnant water at bottom (M. Herz, pers. comm., July 10, 2019). The recent springs of karst 
groundwater $\left(11.6\right.$ to $\left.13.6^{\circ} \mathrm{C}\right)$, located $\sim 120-150 \mathrm{~m}$ south-west to west from the Plavecká jaskyña, are up to $3^{\circ} \mathrm{C}$ warmer than the mean annual temperature of the area (Fig. 2C).

\section{METHODS}

The updated speleological map of the PLA, compiled by P. Magdolen in 2005-2007 (Fig. 3; published in Hubek \& Magdolen, 2008), was used for the recent additional geomorphological and geological survey of the cave in 2018 with the focus on presence of ascending/hypogene morphologies. Detailed cave morphology survey was realized mainly in selected cross-sections in the middle and lower evolution levels. Cave pattern, medium- and small-scale morphology forms were investigated and classified to clarify the genesis of the cave. Results were compared with descriptions in studies focused on sulfuric acid caves (Egemeier, 1981; Hill, 1987, 1990; Palmer \& Hill, 2005; Audra et al., 2007, 2009a, b; Audra, 2008; Plan et al., 2012; Palmer, 2013, 2016; Temovski et al., 2013; Vattano et al., 2013; De Waele et al., 2016. Morphostratigrahical relationships of older and younger morphologies were distinguished and explained to reconstruct respective evolution phases in the cave. The aim of the geological survey was mainly the collection of structural data, with a particular focus on brittle structures, as they represent the most viable water-flow paths in the rock, and thus represent a crucial element in the formation of the cave. Data were collected with a Freiberger geological compass and processed in the Stereo32 software (Röller \& Trepmann, 2003), an equal-area rose diagram of measured structures was constructed. Most significant discontinuities were also noted in the cave map. Other aims of the geological survey were to cursorily asses the lithology of host rocks and attempt to identify minerals that could point to the hypogene origin of the PLA. The field survey was completed by photographic documentation.

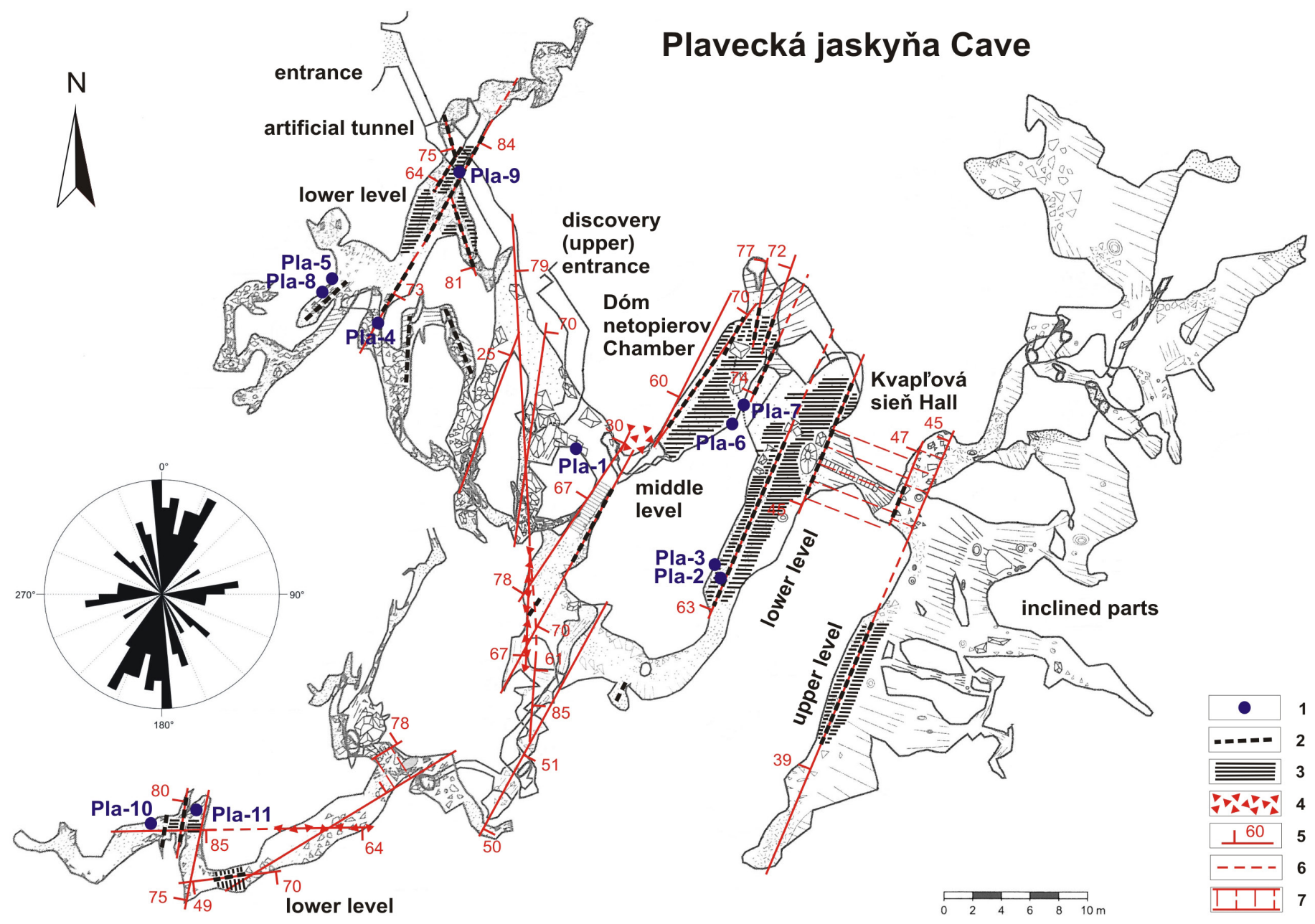

Fig. 3. Map of the Plavecká jaskyňa (after surveys of Magdolen et al., 2002-2007 printed in Hudek \& Magdolen, 2008): 1) sampling site, 2) fissure discharge feeder, 3) flat corrosion floor, 4) breccia, 5) orientation, dip direction, and dip angle of most prominent discontinuties, 6) expected continuation of discontinuties, 7) discontinuity intersecting several levels of the cave. Equal-area rose diagram displaying the strike of the discontinuities measured in the PLA, processed using Stereo32 software (Röller \& Trepmann, 2003): N = 52; maximum = 3.5; strike direction ( $5^{\circ}$ classes); dashed lines represent an interval of $22.5^{\circ}$.

The spatial distribution of cave deposits was studied in relation to phases of hypogene and epigene speleogenesis. Different cave deposits and weathering products from walls and floors of middle and lower evolution levels were sampled for mineralogical (XRD) and stable isotope analyses (locations see on Fig. 3).
The preparation of powdered samples for XRD analysis included dry crushing on a steel plate and pulverizing to a very fine powder using an agate mill. Then approximately 5-10 $\mathrm{mg}$ of the fine powder was mixed with ethanol into a suspension and applied on a silicon plate. Furthermore, oriented specimens were 
prepared for identification of clay minerals. X-ray powder diffraction investigation was carried out with a Bruker D8 Discover diffractometer equipped with a silicon-strip linear LynxEye detector and a focusing germanium primary monochromator of Johansson type providing $\mathrm{CuKa} 1$ radiation $(\lambda=1.54056 \AA)$. Data for mineral identification were collected in the $2 \Theta$ range of $4-75^{\circ}$ with a step size of $0.017^{\circ}$ and counting times of 0.5-0.7 second at each step, and detector angular opening of $1.996^{\circ}$. Data for identification of clay minerals were collected in the $2 \Theta$ range of $2-40^{\circ}$ with a step size of $0.017^{\circ}$ and a counting time of 0.7 seconds at each step, and detector angular opening of $0.998^{\circ}$. The phase identification was performed with DIFFRAC.EVA software (Bruker AXS GmbH, Karlsruhe, Germany; 2010-2018). Semi-quantitative estimation of the mineral composition was calculated by the reference intensity ratio method implemented in Diffrac.Eva software. Analyses were carried out in the Department of Analytical Methods at the Institute of Geology of the Czech Academy of Sciences in Prague.

The oxygen and carbon stable isotopic composition analyses of limestone bedrock and overlying calcite popcorn were performed in the Stable Isotope Laboratory (Institute of Geological Sciences, Polish Academy of Sciences) in Warsaw. Samples were collected by drilling in the profile from unaltered limestone bedrock to calcite popcorn (cave coralloids) top using MicroMill device. The isotopic composition was measured using Thermo KIEL IV Carbonate Device connected to a Finnigan Delta Plus IRMS spectrometer in a Dual Inlet mode. The $\mathrm{CO} 2$ from calcite was extracted using orthophosphoric acid at $70^{\circ} \mathrm{C}$. The international standard NBS 19 was analyzed per every ten samples. The isotope ratios are reported as delta $(\delta)$ values and expressed relative to the V-PDB standard. The measurement precision $(1 \sigma)$ was $0.07 \%$ and $0.03 \%$ o for oxygen and carbon, respectively.

\section{CAVE MORPHOLOGY}

\section{Cave pattern and tectonics}

The PLA is a maze cave controlled by parallel steep fractures and faults (parallel with a fault-controlled slope above the cave) through which rising fluids were discharged. The most numerous set of discontinuities in the cave is represented by the fractures striking
N-S to NNE-SSW and occasionally NNW-SSE. These also played the most significant role in the cave origin and morphology, as the vast majority of cave spaces are predisposed on them (Fig. 3). Another major subset prevalent in the measured discontinuities is represented by fractures oriented generally towards $\mathrm{E}-\mathrm{W}$. However, this type of discontinuity has only minor importance, particularly in the south-eastern part of PLA (Fig. 3). The fractures striking towards NW-SE, as well as NE-SW, are scarcely present in the overall dataset of measured discontinuities ( 3 and 1 of 52 discontinuities respectively. Their influence on the cave morphology is very limited, and only the NESW fractures influence the cave morphology, in the south-eastern part of the cave (Fig. 3).

The PLA consists of morphologically different segments: (i) horizontal and subhorizontal passages and halls; with flat corrosion bedrock floors (in some places terraced), wall water-table notches, and inactive discharging feeder fissures on the floors; (ii) vertical chimneys and high cupola-like cavities; (iii) narrow fissure passages, enlarged fissures with spongework cavities, and similar phreatic morphologies; (iv) steep narrow feeder fissures below (and between) horizontal and subhorizontal passages and halls, and (v) inclined enlarged fissure cavities with cupolas above the upper subhorizontal passage.

The floors of horizontal and subhorizontal epiphreatic passages and halls occur in four vertical positions at 212, 214, 220, and $225 \mathrm{~m}$ a.s.1. (Fig. 4). The larger Dóm netopierov Chamber (at the middle level) and Kvaplová sien Hall (at the lower level) developed along the major feeder fractures. The highest fracturecontrolled chimneys open in the inclined slope on the surface above the cave (the chimney below the discovery entrance, the chimneys rising from the Dóm netopierov and Kvaplová sieñ). The lowest lying horizontal and subhorizontal passages are in the central, south-western and north-western parts of the cave; the highest lying places are chimneys in the central part and inclined enlarged fissure cavities with cupolas in its south-eastern part.

\section{Chimneys, cupolas and ceiling pockets}

Several wider chimneys (up to $13 \mathrm{~m}$ high), associated cupolas in higher ceiling parts, and numerous ceiling pockets occur mostly in fracture-controlled halls and passages in the central parts of the PLA (Fig. 5).

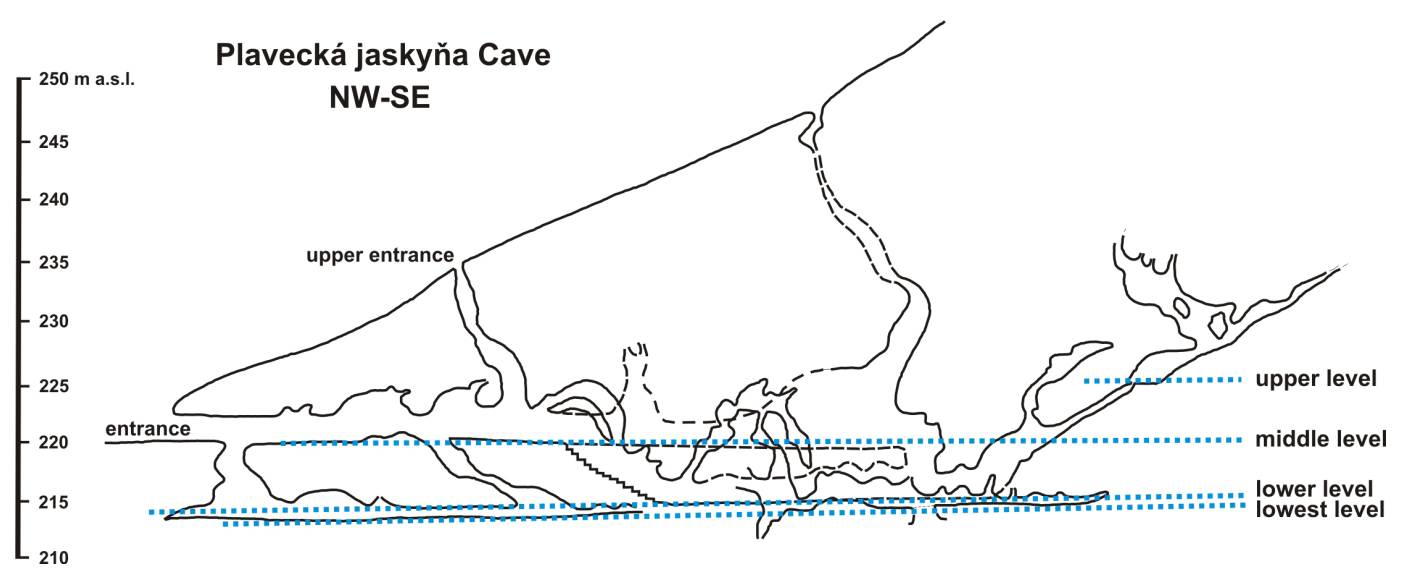

Fig. 4. Schematic cross-section through the Plavecká jaskyňa (after Šmída, 2010; modified) 

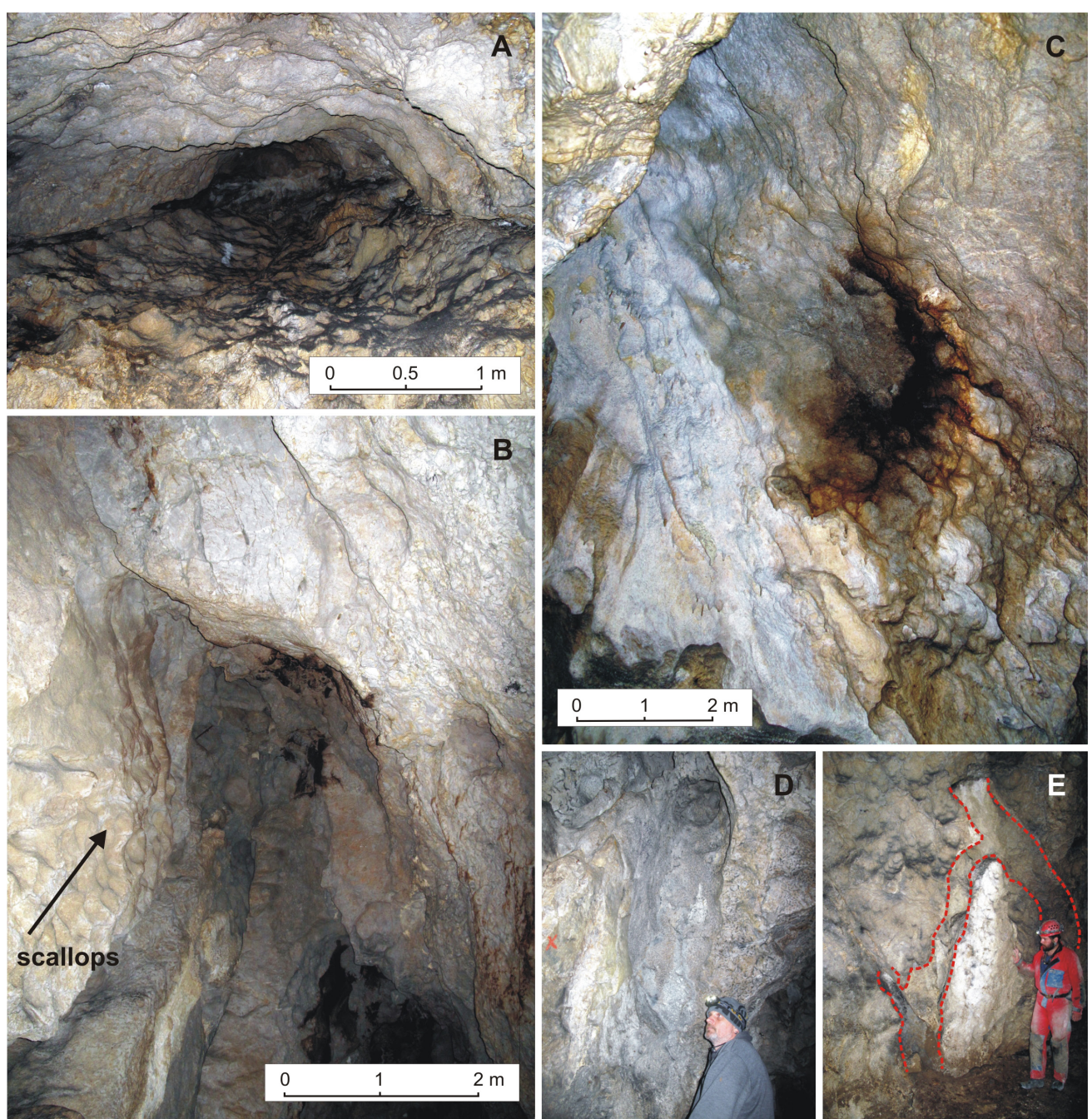

Fig. 5. Phreatic morphologies, Plavecká jaskyňa: A) fault-controlled chimney above the Kvaplová sieň; B) scalloped wall of the upper part of the chimney above the Dóm netopierov; C) cupola above the passage of the upper evolution level; D) upward wall channel closed with a ceiling pocket; E) wall channel rising from feeder (Photo: P. Bella).

They represent one of the dominant morphological features of the cave. Asymmetric scallops on the wall of Dóm netopierov (below one of the chimneys) provide evidence that phreatic chimneys and associated cupolas developed by ascending waters (Bella, 2010; Šmída, 2010; Bella \& Bosák, 2012). Narrow fracturecontrolled chimneys above feeders are observed in many other parts of the cave.

Morphologically different shallow cupolas are observed mostly in lower ceiling positions above the cave floor and not associated with fracture-controlled chimneys (e.g., in the Kvaplová sieñ; Fig. 6).

\section{Feeders}

Steep fissure discharge feeders and associated flat corrosion bedrock floors represent the significant morphology features in the cave. They can be observed in all leveled segments of the PLA (Figs. 3, 7-10).

Fissure discharge feeders (named also 'feeder slots' or 'discharge slots') are controlled by steep fractures (mostly oriented in the NNE-SSW direction, occasionally in the NNW-SSE, and E-W directions). They are truncated by flat floors of horizontal passages and halls. Inactive fissure feeders were recognized by Bella (2010) here. Fissure discharge feeders are usually $0.1-0.2 \mathrm{~m}$ wide (not large enough to allow a person to pass down), in some places they are visible to a depth of $\sim 3$ to $4 \mathrm{~m}$ (e.g., in the Dóm netopierov; Fig. 7). In some places, they are wider (up to $0.35-0.4 \mathrm{~m}$ ) and accessible to the depth of several meters (e.g., in the north-eastern part of Kvaplová sieñ). Šmída (2010) described wide fissures up to $0.1 \mathrm{~m}$, partially remodeled by rising water, on the flat rock floor in the south-western cave parts discovered in 2007. The widest floor fissures (up to 0.6-0.9 m wide) are mostly filled by sediments, and are inaccessible (e.g., in the north-eastern part of the Dóm netopierov and the south-western part of the Kvaplová sieñ; Fig. 7). Fissure feeders on the floor of the north-western passage of lower evolution level (0.1-0.2 $\mathrm{m}$ and $0.5-0.6 \mathrm{~m}$ wide) are artificially filled by limestone debris and boulders (Fig. 9). Other fissure feeders, artificially filled during the building of tourist path and speleological exploration, were identified in the Dóm netopierov and Kvaplová sieñ (partially excavated during our field research).

Steep inclined narrow fissure (in one place passable for a person) leading from the south-eastern edge of the Kvaplová sien up to the subhorizontal passage of upper evolution level can also be interpreted as an inactive fissure feeder. Its lower part intersects the flat corrosion floor in the lower evolution level (at the eastern edge of the Kvaplová sieñ). The fissure feeder is locally visible on the flat rock floor of the passage in 

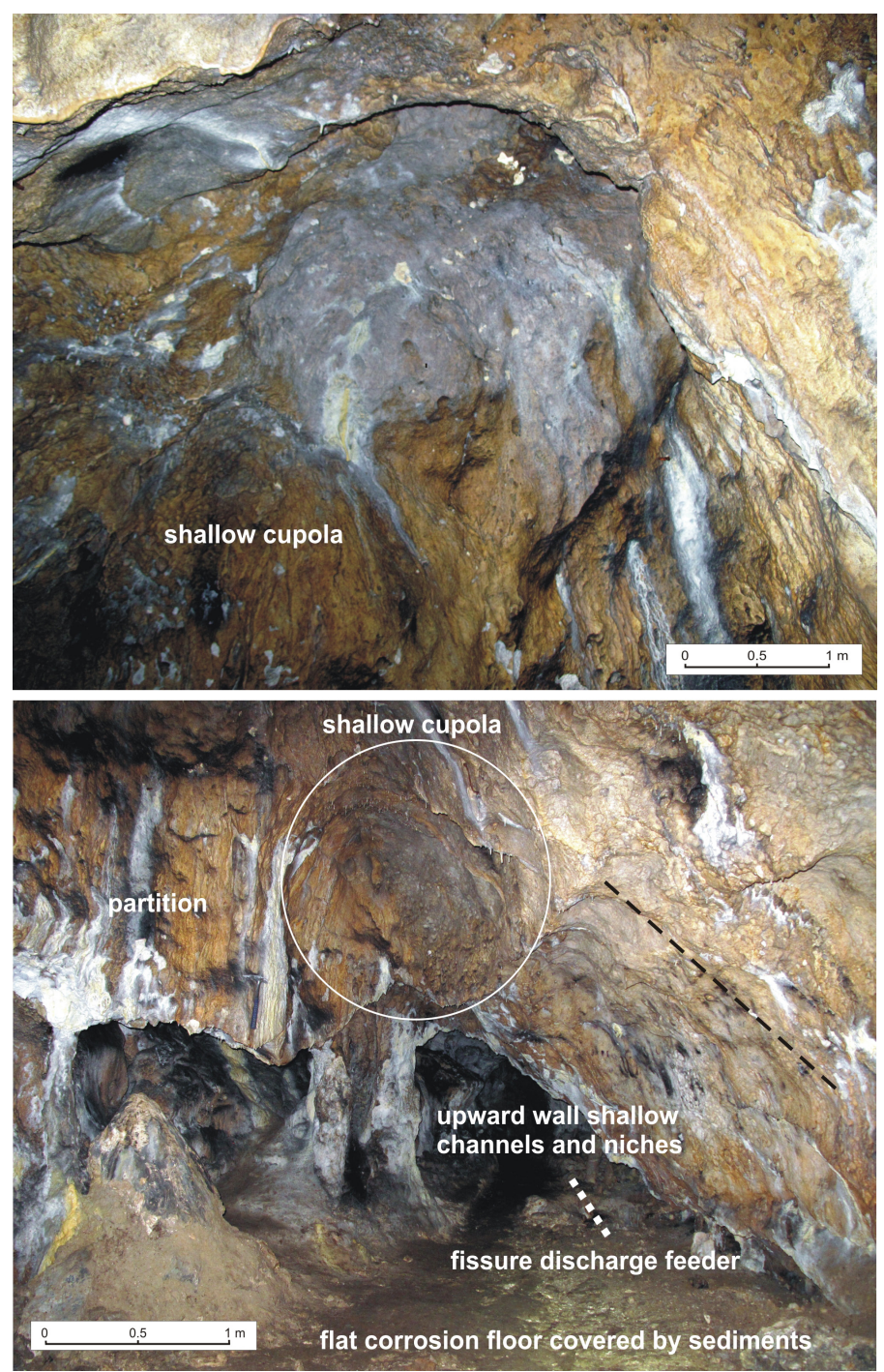

Fig. 6. Shallow cupola and associated morphological features in the Kvaplová sieň, Plavecká jaskyňa (Photo: P. Bella). the cave upper level, but mostly it is filled and covered by fractured flowstone.

In some places, steep fissure discharge feeders are enlarged to channels. The steep channel at the northeastern edge of Dóm netopierov, predisposed at the intersection of two fissure feeders is wide-spread to $0.5-1 \mathrm{~m}$, and its depth is more than $6 \mathrm{~m}$ (accessible for a person; Fig. 7).

\section{Flat corrosion floors}

The bedrock floor surfaces (or 'corrosion tables') are flat and the widest places of passages and halls, and truncate fissure discharge feeders. They were first described by Egemeier (1981) as typical for sulfuric acid speleogenesis (SAS). The bedrock floor surfaces in the PLA are gently inclined to the upper end of fissure feeders (1.9 to $6.8 \%$ ). The flat bedrock floor in the Dóm netopierov, truncating two fissure feeders, is 3.6 $\mathrm{m}$ wide (Fig. 7). Small passage parallel with the northwestern edge of Dóm netopierov represents a smallsized example of flat floor bedrock surfaces (with a lateral notch) very gently inclined to the upper end of fissure discharge feeders (Fig. 7). The vertical span between flat bedrock floors in the Dóm netopierov and this small parallel passage is $0.35 \mathrm{~m}$. The vertical span of floor bedrock surfaces in the north-western passage of lower evolution level is $1.15 \mathrm{~m}$ (the terraced bedrock surface is also dissected by fissure feeders, locally enlarged to elongated downward narrowing holes). Smaller flat floor bedrock surfaces on the sides of fissure feeder are found also in the passage of upper evolution level. Flat bedrock floors are mostly covered by fine-grained sediments, debris, fractured flowstone, and dripstones or moonmilk. Powdery residues from limestone dissolution occur on drier places only.
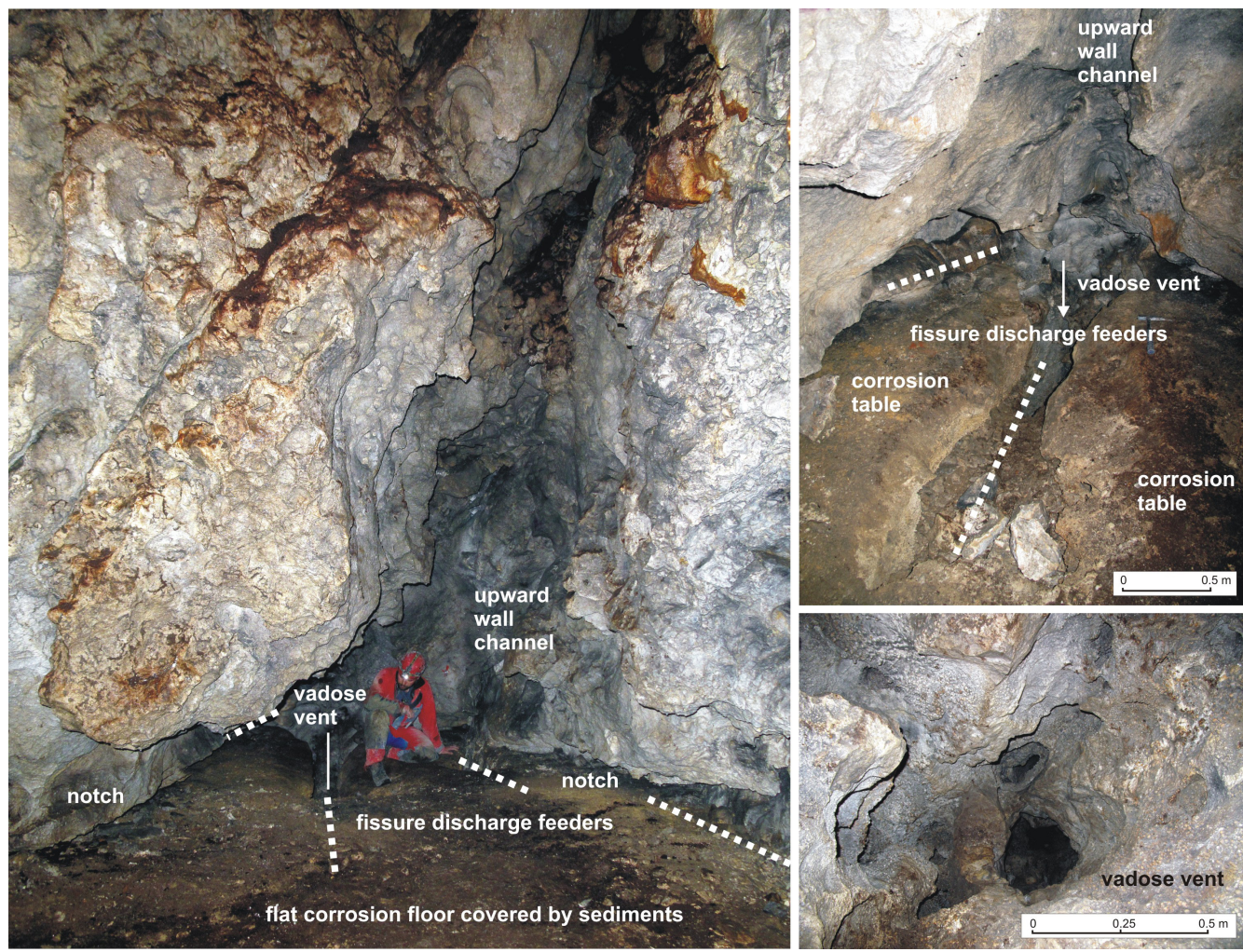

Fig. 7. Fissure discharge feeders and flat corrosion floor surfaces in the north-eastern part of Dóm netopierov, Plavecká jaskyňa (Photo: P. Bella). 
In halls and wide passages, the flat bedrock floor truncate two or even four fissure feeders (in the Dóm netopierov, Kvaplová sieň, as well as in the northwestern passage of lower evolution level; Figs. 7 and 9). This is a result of cave development proceeded by the expansion of cavities around fissure feeders. The remnant of small passage with a fissure feeder, double-sided wall notch, and inward gently inclined floor bedrock surfaces which leads parallelly with the north-western edge of Dóm netopierov (Fig. 8), confirms this assumption. Morphologically, the progressive expansion of neighboring passages is detected by remnants of bedrock partings with concave pillars, pendants, blades, projecting corners or arches.

\section{Water-table wall notches}

Distinct horizontal wall notches are developed at the edges of flat bedrock floor surfaces. Their segments correlate with each other in altitude position throughout the cave level. The lateral notch carved in the south-eastern wall of Dóm netopierov is 0.7 $\mathrm{m}$ long and $0.67 \mathrm{~m}$ high (the middle evolution level). Significant notches also occur in the Kvaplová sieñ and the north-western passage of lower evolution level (Bella, 2010; Fig. 9). Since the wall notches have an almost flat roof or floor surface, adjacent floors of passages and halls have been laterally enlarged in shallow pool conditions along the water table. Stratigraphic control of the origin of the wall notches as well as associated floor bedrock surfaces is unlikely, because host carbonates are massive (without any horizontal fractures).

Smaller wall notches, originated above each other, indicate a former groundwater table oscillations, similar to the nearby Plavecká priepast' (see Šmida, 2010). In the PLA, they occur in the lower evolution level (best to see them in the north-western part of the cave).

\section{Other medium- and small-scale morphologies}

Vertical half-tubes deepened into lower overhanging parts of cave walls are visible at the edges of fissure discharge feeders, mostly in the Dóm netopierov and Kvaplová sieñ. In the north-western passage of lower evolution level, overhanging parts of cave walls above water-table notches are dissected by wall niches and narrow vertical halftubes that lead upward to ceiling channel.

In many places, small pits and hollows of various morphologies, as well as spongework cavities, are deepened into cave walls and ceilings. However, they are mostly covered by moonmilk or flowstones. Box-like pattern, composed of thin blades (intersect
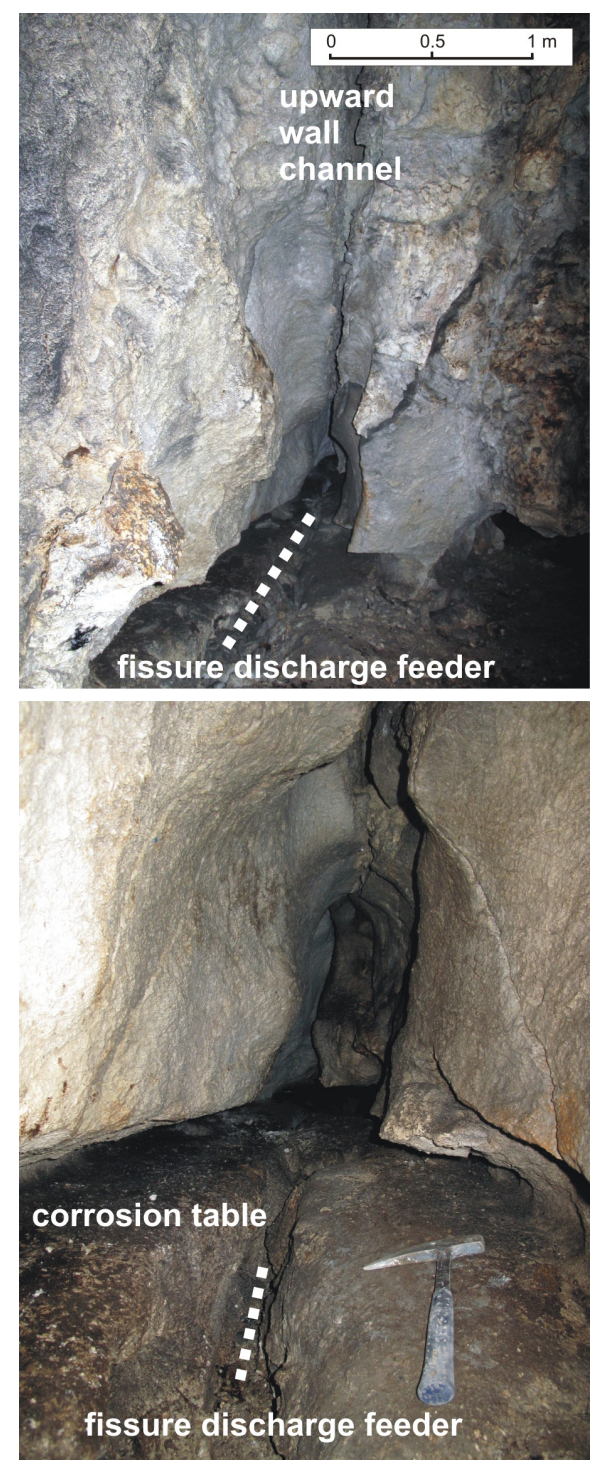

Fig. 8. Morphology of the small passage parallel with the northwestern edge of Dóm netopierov, Plavecká jaskyňa (Photo: P. Bella).
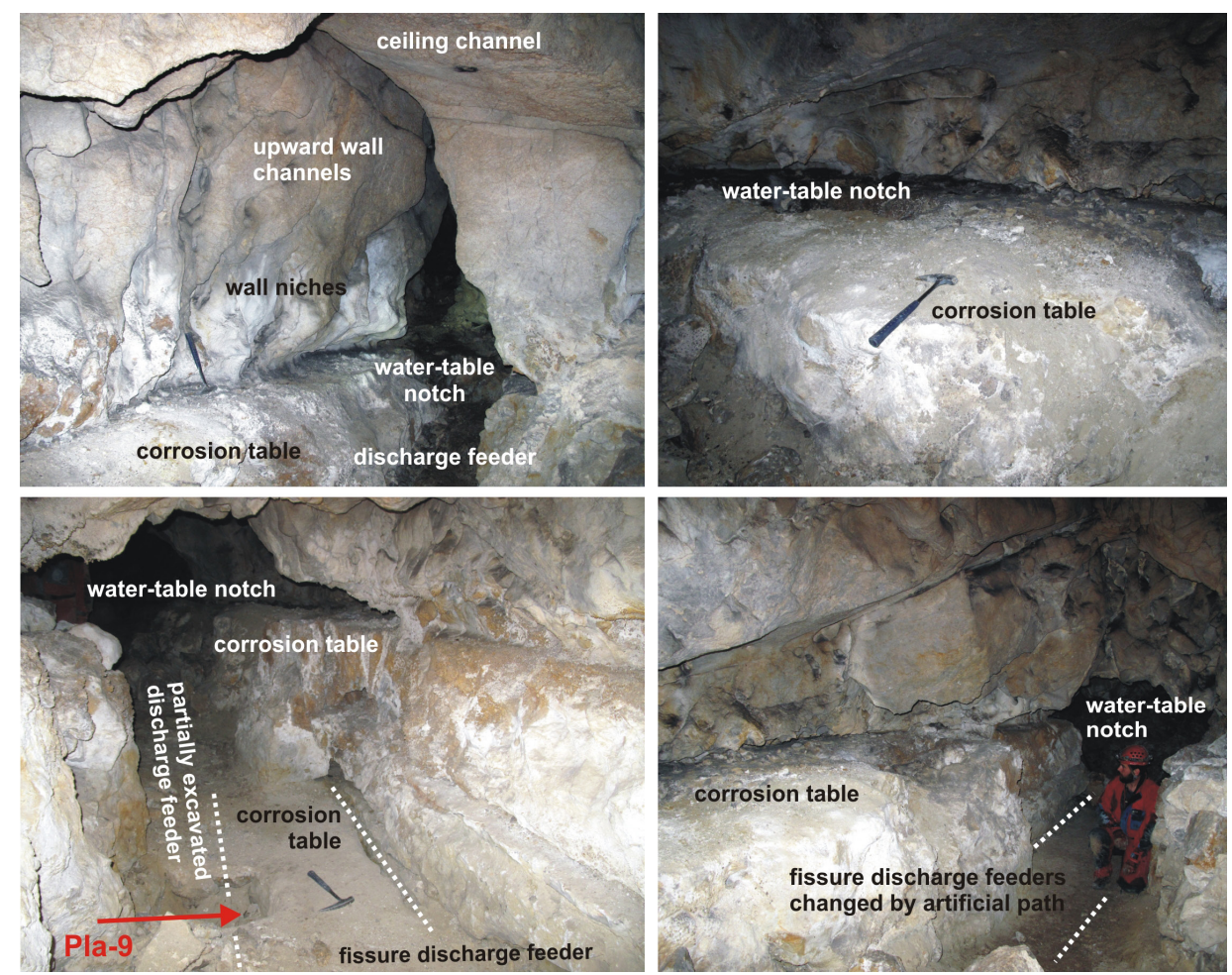

Fig. 9. Water-table notches, terraced floor bedrock surfaces, flat corrosion floor, and fissure discharge feeders in the north-western passage of lower evolution level, Plavecká jaskyňa (Photo: P. Bella). 
one another at various angles) that project from a limestone surface, are rarely visible on overhanging parts of rock walls in the middle evolution level.

\section{CAVE DEPOSITS}

While several passages and halls of the PLA are decorated by dripstones, flowstones, and moonmilk, its floors are covered mostly by fractured flowstone, boulders, and debris; the proportion of fine-grained siliciclastic deposits is very small. But several original floor surfaces have been artificially changed during speleological explorations and the adjustment of tourist paths. Calcite popcorn rims occur mostly on edges and upper parts of feeding fissures, as well as steep condensation-corrosion channels (Fig. 10). Popcorn (popcorn-shaped subaerial corraloids) and similar calcite speleothems (subaqueous corraloids) precipitated on the walls of narrow and high passages of the lowest evolution level in the south-western part of the PLA where feeding fissures are less frequent and narrower. Here, also calcified cave rafts have been found by W. Wróblewski and M. Gradziński on the laterally enlarged floor, i.e., in the place of the former lake.

We sampled nine deposits (Pla-1 to Pla-6, Pla-8 to Pla-10; for positions see Fig. 3) from cave walls outside deposits of bat excrements, if possible. Samples were mostly composed of soft, milky white to beige matter, mostly fresh to matured moonmilk. One sample (Pla1) was greenish grey fine-sandy mud, filling corroded fissures in cave wall near the entrance. Sample Pla-9 was composed of pale yellow deposit of sandy appearance in a partly excavated discharge feeder in the flat floor of the lower evolution level (Fig. 9).

The studied samples are dominated by carbonates (calcite and dolomite). In addition, quartz, feldspars, micas, clay minerals, gypsum, and alunite were identified (Table 1). They are less frequent. The presence of micas and clay minerals has been indicated in powder samples Pla-1 and Pla-9. Based on the measurement of the oriented specimens, kaolinite, montmorillonite and minerals from the mica and chlorite group were determined.
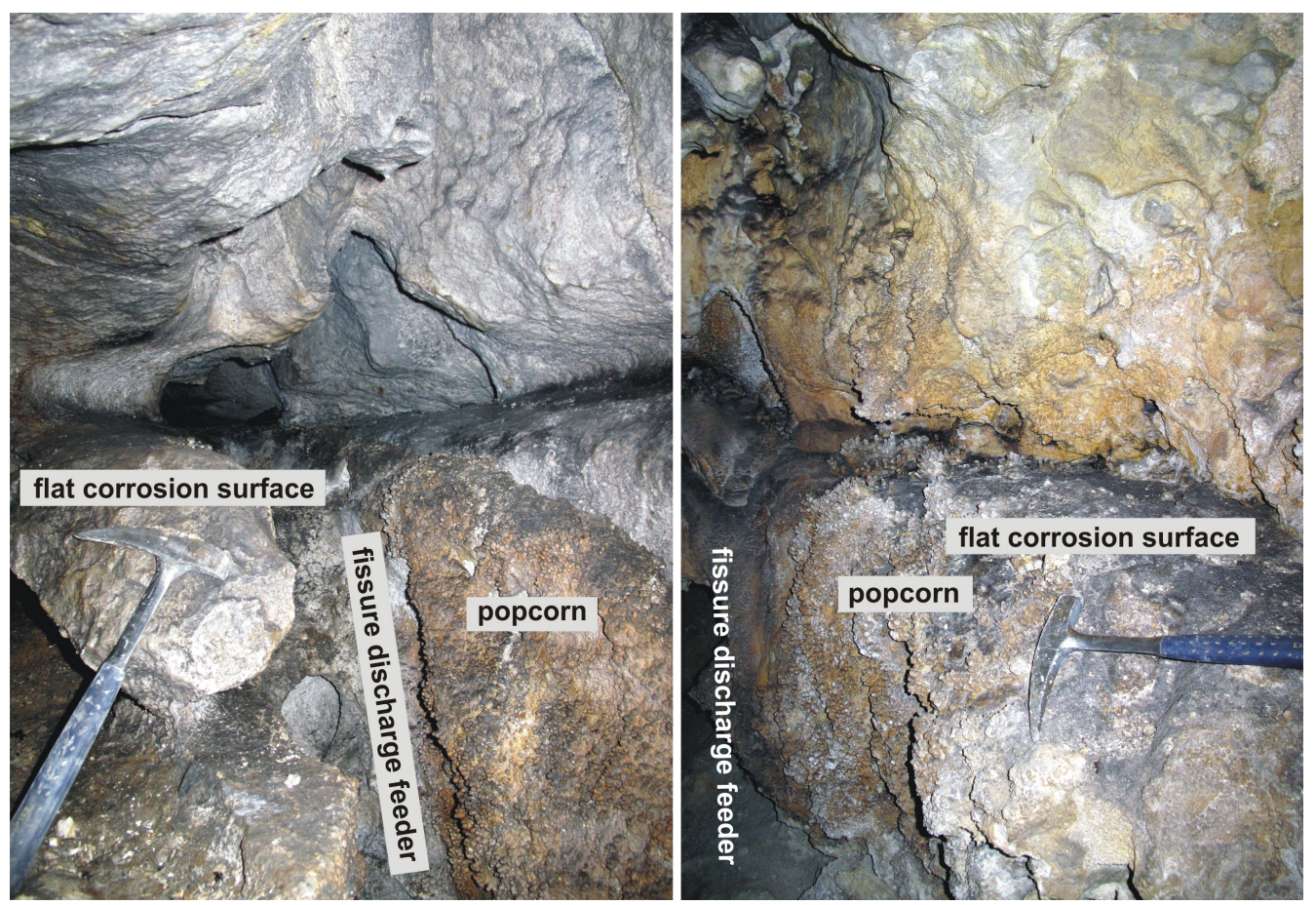

Fig. 10. Calcite popcorn rims on edges and upper parts of fissure discharge feeders, Plavecká jaskyňa (Photo: P. Bella).

Table 1. Semi-quantitative mineral composition of bulk samples determined by XRD (composition in wt\%).

\begin{tabular}{|c|c|}
\hline Calcite & $29.0-100.0$ \\
\hline Dolomite & $24.6-41.8$ \\
\hline Quartz & $1.1-4.8$ \\
\hline Mica group ${ }^{a)}$ & $9.2-12.2$ \\
\hline Kaolinite & $2.2-4.1$ \\
\hline Chlorite group ${ }^{b)}$ & $<5.0$ \\
\hline Montmorillonite & $<3.0$ \\
\hline Gypsum & $<3.0$ \\
\hline K-feldspars ${ }^{c}$ & $<3.0$ \\
\hline Alunite & $<1.0$ \\
\hline
\end{tabular}

a) muscovite and illite

b) clinochlore

c) microcline or orthoclase

\section{STABLE ISOTOPES}

The profile across a piece of limestone bedrock covered by calcite popcorn (sample Pla-11 taken from the wall of lower evolution level; Fig. 3) revealed changes in the $\mathrm{C}$ and $\mathrm{O}$ isotopic composition (Fig. 11). The Triassic Wetterstein Formation (marine carbonate) has $\delta^{13} \mathrm{C}$ and $\delta^{18} \mathrm{O}$ values of -0.3 to $-2.7 \%$ o and -0.1 to $-1.6 \%$ VPDB, respectively. However, in the $3 \mathrm{~mm}$-thick uppermost zone of limestone bedrock on the cave wall, both isotope values gradually become more negative toward the cave wall. The minimum $\delta^{13} \mathrm{C}$ and $\delta^{18} \mathrm{O}$ values are -4.1 and $-3.8 \%$ VPDB, respectively. The more distinct difference in the isotopic composition was detected between the altered most upper part of limestone bedrock and the 
overlying calcite popcorn. The popcorn, with a total thickness of $10 \mathrm{~mm}$, consists of two different parts. Within its lower thin layered part ( $3 \mathrm{~mm}$-wide), $\delta^{13} \mathrm{C}$ and $\delta^{18} \mathrm{O}$ values oscillate from -7.2 to $-9.0 \%$ and -4.2 to $-8.6 \%$ o VPDB, respectively. Within its upper thicker layered part ( $7 \mathrm{~mm}$-wide), $\delta^{13} \mathrm{C}$ becomes more positive (from -9.0 to $-4.0 \%$ o VPDB) and $\delta^{18} \mathrm{O}$ more negative (from -7.0 to $-9.7 \%$ o VPDB).

Sulfur isotopic, as well as isotopic parameters of $\mathrm{C}$ and $\mathrm{O}$ in gypsum, cannot be presented due to negligible to the very low yield of gypsum dissolution from the Pla-9 sample (K. Žák, pers. comm., December $7,2018)$.

\section{DISCUSSION AND INTERPRETATION}

\section{Phreatic morphologies sculpted by ascending water}

Rounded, scalloped or protruding bedrock morphologies preserved in high chimneys controlled by fractures, as well as ceiling pockets in the adjacent cave parts, probably originated in the phreatic zone by ascending water (Fig. 5). Asymmetric, mostly mediumscale scallops indicate former upward water flow, e.g., on the wall of Dóm netopierov (Bella, 2010; Šmída, 2010; Bella \& Bosák, 2012) or in the wider and higher parts of the passage of upper evolution level. Moreover, upward channels more deepened into bedrock walls, observed mostly below high fracture-controlled chimneys, originated by water rising along vertical fissures. However, these older phreatic morphologies can be partly changed by condensation corrosion due to a SAS (see below). In consequence of rising water flow along a deep fault zone and phreatic conditions (without transport of allochthonous sediments from the surface and carbonate speleothem formation), the oldest phase of cave origin and development is not evidenced by sedimentary fills.

\section{Epiphreatic and vadose morphologies related to an intensified sulfuric acid dissolution}

The PLA is characterized by several morphologies that correspond with fracture-controlled caves of multi-phased hypogene origin, partly sulfuric acid caves related to changes of the base-level.

Flat corrosion floor surfaces (or 'corrosion tables') truncating fissure discharge feeders, also frequently occurred in the PLA, belong to main morphological indicators of hypogene sulfuric caves originated along water table (Egemeier, 1981; Audra, 2008; Audra et al., 2009a, b; De Waele et al., 2016). Moreover, upward half tubes and channels on the overhanging walls of halls and passages are associated with fissure discharge feeders.

Tectonic fractures, which predisposed fissure discharge feeders, high cupolas, and chimneys, are mostly linked either with the NE-SW-trending Leitha faults (as part of the VBTF) separating Male Karpaty and Záhorská nížina (Bella, 2010; Bella \& Bosák, 2012), or faults oriented generally in the N-S direction, that intersect the Leitha faults in the vicinity of PLA. Some other fissure discharge feeders are controlled by transverse NW-SE and E-W-trending discontinuities

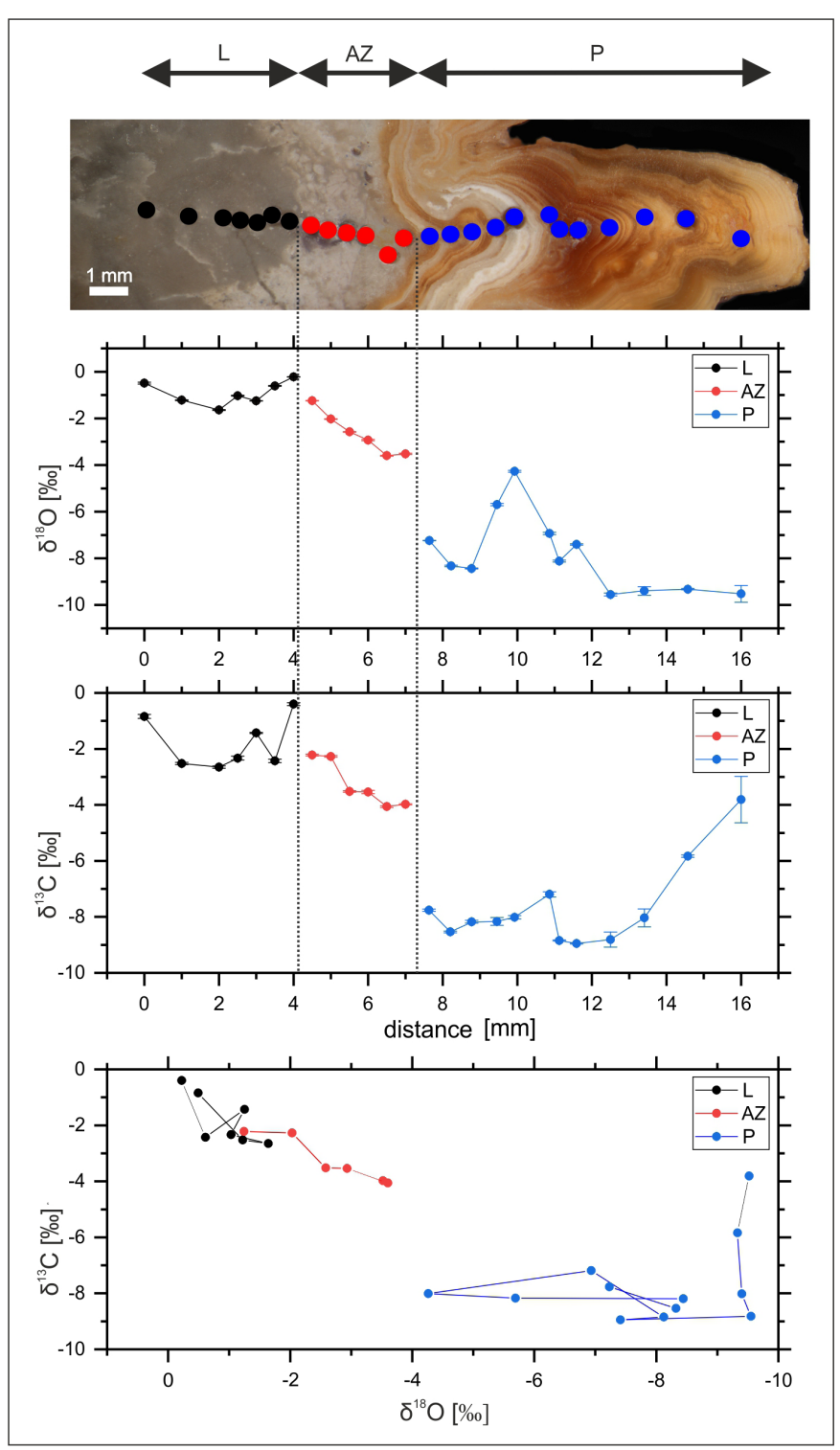

Fig. 11. Stable isotopic composition of limestone bedrock and calcite popcorn precipitated on the cave wall of lower evolution level (sample Pla-11): L) intact (unaltered) limestone bedrock; AZ) alteration zone in the uppermost part of limestone bedrock; P) calcite popcorn.

(e.g., in the north-western part and the south-western edge of the cave). According to Šmida (2010), these fractures resulted from slope gravity movements. With regard to a deeper circulation of rising water, the tectonic origin of these fractures is likely.

The flat corrosion floor surfaces in the PLA can be compared with smooth 'corrosion tables' formed by acid condensation waters (condensation sheet-runoff) flowing back to the feeding fissure or pool described by Audra (2008), Audra et al. (2009b), and De Waele et al. (2016). Since flat corrosion floor surfaces in the PLA are laterally associated with wall water-table notches (Fig. 9; see also the cross-section of the small passage parallel with the north-western edge of Dóm netopierov on Fig. 8), their origin can be linked rather with the water table and its repeated slight oscillations. Also, Galdenzi (2012) notes that wall notches with corrosion flat surfaces on both sides of fissure feeders in the Grotta del Fiume (Frasassi, Italy) formed when the passage was partly flooded by sulfidic water. Because the amount of dissolved oxygen decreases below the water table with depth (Egemeier, 1981; Hill, 1990 and others), shallow pools on sides of 
fissure feeders allow the formation of sulfuric acid by oxidation of H2S dissolved in ascending fluids which rapidly dissolves the limestone bedrock. Bedrock was dissolved mostly on the inclined floor surfaces of wall notches when water film was flowing down after repeated drops of the water table. Due to greater water movement, the oxidation is most rapid where the floor gradient is steepest and slowest where the gradient is flattest. The very gentle floor gradients in sulfuric acid caves are probably controlled by oxidation rather than the water table (Egemeier, 1981). Silt deposited on the cave floor protects limestone from dissolution (Hill, 1990), therefore the floor is laterally enlarged to both sides.

Wall water-table notches and flat corrosion floor surfaces, in some places slowly inclined inward to fissure discharge feeders, represent the widest places of lateral enlargement (widest cross-sections) in the PLA. Original phreatic morphologies had been renewed and enlarged under epiphreatic and vadose conditions due to low-temperature sulfuric acid dissolution.

Wall convection niches above a water-table notch, visible along the edge of flat terraced corrosion surface in the north-western passage of lower evolution level (Fig. 9), have been formed by condensation corrosion due to rising air (convection cells) above a thermal pool (see Audra et al., 2009b; De Waele et al., 2016). Before the excavation of artificial tunnel leading into lowerlying parts, the PLA had only one small chimney-like opening to the surface, probably uncovered during the younger phase of slope denudation. Originally, stable or very sluggish air circulation was in the cave (the artificial opening is now closed by an iron door to minimize the changes of cave climate). Since lowtemperature water ascended into the lower parts of
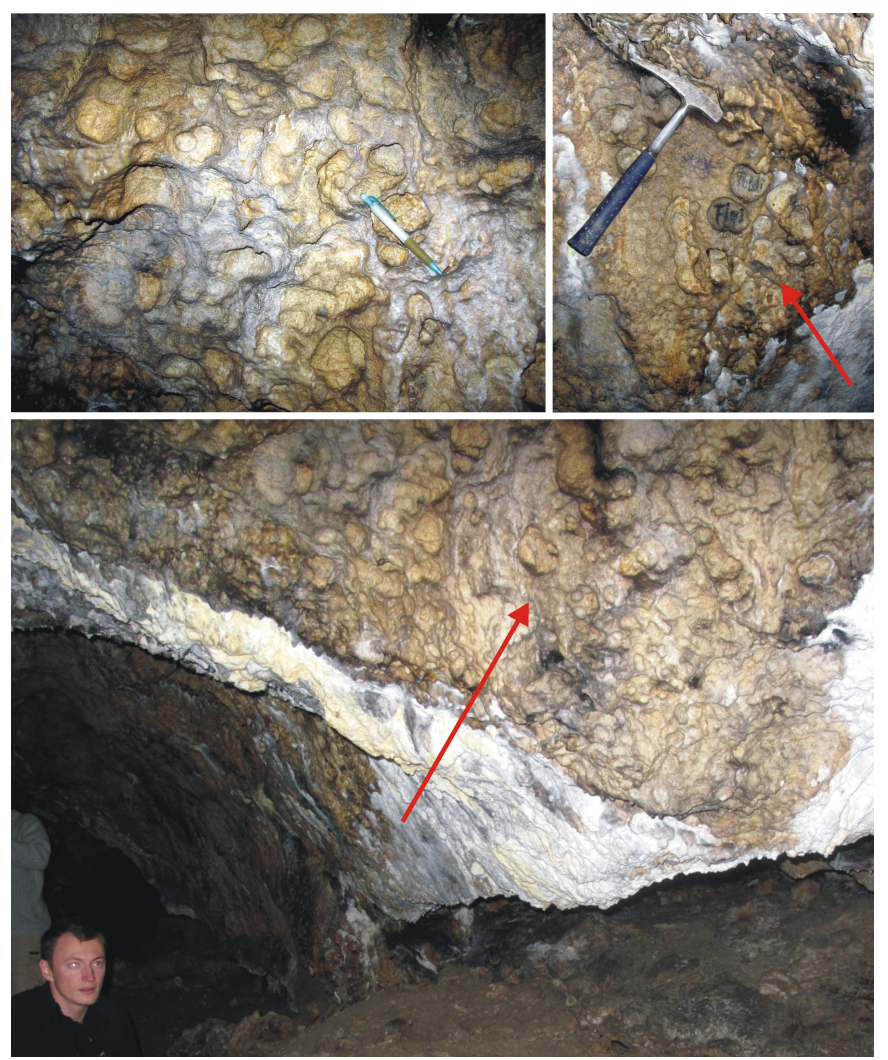

Fig. 12. Replacement pockets, Plavecká jaskyňa (Photo: P. Bella). the cave, the slightly warmer air rised from the water table into the higher cave parts. Upward channels and half tubes lead from convection niches to a ceiling channel. Wall convection niches above a water-table notch also support the assumption for the origin of flat corrosion floor surfaces along the oscillating water table.

More distinct vertical upward channels, deepened into lower overhanging parts of cave walls at the edges of fissure discharge feeders (above flat corrosion floor surfaces; Figs. 6 and 7); were formed by condensation corrosion in places of concentrated outlets of rising warm air. Due to unequal intensive outlets of rising warm air, upward channels above water-table notches are shallower than ones originated above the edges of fissure discharge feeders.

Shallow cupolas in lower ceiling positions above the cave floor also originated by condensation corrosion in vadose conditions. However, condensation corrosion megascallops as well as high and large cupolas, typical for some sulfuric acid caves (see Audra et al., 2009b; Plan et al., 2012; De Waele et al., 2016), are missing in the PLA. Therefore it can be assumed that condensation-corrosion forms in the PLA were formed nearly exclusively in the lower parts of cave passages and halls due to a low-thermal gradient among the ascending water, cave air, and bedrock. In the PLA, $\mathrm{H}_{2} \mathrm{~S}$ was degassed from stagnant pools, i.e., much less than from turbulent, flowing waters in some other sulfuric acid caves (see Galdenzi, 2012; Jones et al., 2015). Longer (extending to higher parts of cave passages and halls) and more deepened upward wall channels which originated above tubelike feeders, as well as high fault-controlled chimneys and other associated morphologies, probably resulted from the primary (pre-sulfuric acid) phase of cave development.

Subhorizontal passages and halls with epiphreatic wall water-table notches and flat corrosion floors and terraces occurred in above-mentioned four vertical positions, are interpreted as evolution levels. They developed in relation to vertical positions of the spring of underground waters at the foot of the Plavecky hradny vrch during phases of repeated interrupted fall of erosion base level related to the movements along the Leitha faults or intersecting faults. The stabilization of erosion base level could result from the deccelearated or interrupted subsidence of the Podmalokarpatská zníženina, sedimentary aggradation during the subsidence, or possibly by other causes related to the landform evolution in the adjacent part of the Vienna Basin.

After the water table drops, fissure discharge feeders functioned as thermal vents supplying the rising moist air. In places of most concentrated and intensive air discharge, they were enlarged to condensationcorrosion channels, e.g., at the north-eastern edge of Dóm netopierov (Fig. 7).

Hemispherical corrosion hollows with diameters of some centimeters to more than $1 \mathrm{dm}$ embedded into the limestone walls (Fig. 12) can be classified as replacement pockets that are formed by concentrated sulfuric acid corrosion on limestone walls exposed 
to $\mathrm{H}_{2} \mathrm{~S}$ vapors, with the simultaneous replacement of calcite by microcrystalline gypsum. In several sulfuric acid caves, corrosion pockets represent the only evidence of a preexisting gypsum crust that was dissolved by seepage water (Galdenzi \& Maruoka, 2003).

Small lithologically-conditioned solution spongeworklike hollows in high density are characteristic for cave walls and ceilings on carbonate breccias that probably represent a fill of palaeokarst cavity (occurred in the south-western edge of Dóm netopierov and on the ceiling of the passage leading from the south-western edge of Dóm netopierov to the lower evolution level).

Boxwork on overhanging parts of rock walls formed by condensation corrosion differentially attacked the bedrock, slowly dissolving the rock among less soluble mineral veins in limestone and leaving a powdery residue (see Zupan Hajna, 2003).

\section{Isotopic alteration during water-limestone bedrock interaction}

The thin $(3 \mathrm{~mm})$ alteration zone in the uppermost part of limestone bedrock (in sample Pla-11) was detected by changes of isotopic composition $\left(\delta^{13} \mathrm{C}\right.$ values of -2.2 to $-4.0 \%$ o and $\delta^{18} \mathrm{O}$ values of -1.2 to $-3.7 \%$ o VPDB; Fig. 11). Considering that the mean isotopic composition of deep-seated carbon is estimated $-5.2 \%$ and the range is -2 to $-8 \%$ o (Deines and Gold, 1973), the uppermost part of limestone bedrock in the PLA $\left(\delta^{13} \mathrm{C}\right.$ values range from -2.2 to $-4.0 \%$ VPDB) was slightly altered by solutions containing deep-seated carbon. This alteration zone, with a low-amplitude alteration trend $\left(\delta^{13} \mathrm{C}\right.$ and $\delta^{18} \mathrm{O}$ shifted toward lower values by $1.8 \%$ ond $2.5 \%$ VPDB, respectively), is a result of the water-limestone bedrock interaction during phreatic, most probably the hypogene phase of cave development.

The same or very similar changes of isotopic composition and a low-amplitude alteration trend was detected in the carbonate bedrock below the surface of cave walls in several other hypogene/hydrothermal caves (see Bakalowicz et al., 1987; Hill, 1987; Sarbu \& Lascu, 1997; Bottrell et al., 2001; Dublyansky \& Spötl, 2009; Spötl et al., 2009; Palmer \& Palmer, 2012; Dublyansky et al., 2014).

Former solutions had dissolved inorganic carbon about 2-3\% lighter than the unaltered limestone bedrock; however, much heavier than the isotopic composition in the younger overlying calcite popcorn. This calcite popcorn precipitated from solutions with a different isotopic composition than the one that altered the bedrock; therefore, the surface part of alteration zone could be partially eroded.

\section{Sulfate mineral by-products of sulfuric acid speleogenesis}

Almost monomineralic specimens (Pla-2 to Pla-6 and Pla-8) represent moonmilk typically with predominant calcite composition. Some dolomite and/or quartz admixtures most probably represent insoluble residuum after the dissolution of the bedrock.

Very low occurrences of alunite $(<1 \mathrm{wt} \%$, according to the XRD) and gypsum ( 2 wt\% vs $0.15-0.20 \%$ from sample leaching) in sample Pla-9 (Tab. 1) indicate a presence of sulfate-low waters which causes lateral corrosion and precipitation of gypsum and alunite under significantly acidic conditions. Alunite precipitation is controlled by sulfatic-rich solutions with $\mathrm{pH}$ 's at or below 5 (Rodriguez-Clemente \& Hidalgo-Lopez, 1985). Low hydrogen sulfide concentrations and rare fine-grained siliciclastic cave sediments probably do not allow the massive formation of gypsum and alunite group minerals (like jarosite). Fine-grained siliciclastic deposits were preserved in places in the cave after excavation during earlier stages of cave evolution (e.g., sample Pla-1).

Gypsum and alunite support the idea about SAS together with above-mentioned morphological indicators (corrosion plates/flat floor surfaces and associated wall water-table notches). In sulfuric acid caves, carbonate rock at or near water table, as well as on walls and ceiling above the water table, is attacked by sulfuric acid (resulted from the oxidation of $\mathrm{H}_{2} \mathrm{~S}$ ) and converted to gypsum (Egemeier, 1981; Hill, 1987, 1990; Galdenzi \& Maruoka, 2003, 2019). The alunite in intimate association with hydrated halloysite in deposits is clear evidence of the alteration of clay by sulfuric acid (Polyak \& Güven, 1996; Polyak \& Provencio, 1998, 2001; D'Angeli et al., 2018); unfortunately, halloysite was not clearly proved by detailed XRD analyses in the PLA.

We assume that most of the products of gypsum metasomatism on walls and floors of the cave have been removed by later dissolution under wet conditions due to a periodic intensive vadose percolation (the PLA is formed in highly fractured carbonates, mostly along steep to vertical fractures; its underground spaces recently occurs up to 30$35 \mathrm{~m}$ below the slope of Plavecký hradný vrch) or repeated water table oscillations. Corrosion of calcite crusts in several places of the cave represents also the consequences of increased cave humidity. Without a relatively intensive vadose percolation, there would be no rich calcite decoration (moonmilk, flowstones and dripstones), mostly in the passages of upper and lower cave levels. The origin of some corrosionally enlarged steep and inclined fissures in the upper part of the cave as well as numerous floor pits formed by dripping water (e.g., in the Dóm netopierov) is also linked with vadose percolation.

\section{Calcite popcorn precipitation}

Carbon-oxygen signatures of calcite popcorn in the PLA (sample Pla-11, Fig. 11) show that it precipitated mostly under subaerial conditions. Only $\delta^{13} \mathrm{C}$ values of -7.2 to $-7.5 \%$ ond $\delta^{18} \mathrm{O}$ values of -4.0 to $-5.2 \%$ o VPDB in the middle (white layers) of lower thin layered part of studied popcorn correspond with the stable isotopic composition of subaqueous coralloids (compared with data given by Caddeo et al., 2015; see also Fairchild \& Baker, 2012). This part of popcorn probably precipitated in a former short-lived shallow lake at the lowest evolution level. Cave rafts formed on the water table of this lake.

Generally, subaerial calcite popcorn (subaerial coralloids) precipitates in places where evaporation 
dominates (Thrailkill, 1971; Hill, 1987; Caddeo et al., 2015). Evaporation processes in sulfuric acid caves have occurred only at the edges of fissure discharge feeders by subsident cooler and drier air leading to the deposition of calcite as popcorn rims (De Waele et al., 2016). Subaerial calcite popcorn rims (Fig. 10) originated when the water table dropped deeper but fissure discharge feeders were still active as thermal vents above reservoirs of warmer water. Rising vapors caused condensation-corrosion processes on the cooler overlying walls and roof.

The stable isotopic composition of the upper thicker layered part of studied popcorn $\left(\delta^{13} \mathrm{C}\right.$ values of -9.0 to $-4.0 \%$ and $\delta^{18} \mathrm{O}$ values of -7.0 to $-9.7 \%$ vPDB) suggests that it precipitated mostly due to degassing of condensation water. The abrupt enrichment in $\delta$ ${ }^{13} \mathrm{C}$ with small changes in $\delta^{18} \mathrm{O}$ probably resulted from rapid fluid degassing (see Gonzalez \& Lohmann, 1988) or from deep-seated carbon contained in solutions.

The lower part, as well as the bottom of the upper part of studied popcorn, precipitated from solutions containing predominantly atmospheric carbon $\left(\delta^{13} \mathrm{C}\right.$ in the atmosphere is $\sim-8 \%$ ). $\delta^{18} \mathrm{O}$ values within the upper thicker layered part of popcorn to a great extent correspond with the mean annual $\delta^{18} \mathrm{O}$ value in precipitation in the PLA area $(\sim-9.5 \%$; see Holko et al., 2012).

\section{Cave origin in relation to hydrogeological settings along the VBTF}

Fault-controlled chimneys and cupolas of phreatic morphology, as well as described morphologies of SAS point to the formation of the PLA by waters ascending along the Leitha faults of VBTF between Male Karpaty and Záhorská nížina (Bella, 2010; Bella \& Bosák, 2012; Bella \& Gaál, 2012, 2017). The waters could also ascend along the $\mathrm{N}-\mathrm{S}$-trending faults that intersect the Leitha faults in the cave vicinity. Structural and geological settings allow deeper circulation of underground waters from the karst hydrogeological structures of the Pezinske Karpaty into Quaternary and Neogene sediments of the Záhorská nížina (Kullman, 1966, 1980, 1990).

In the surrounding of Plavecký hradný vrch, meteoric waters infiltrate into karst aquifers predominantly through fault-controlled narrow depression (Bukovská brázda) between the main range of the Male Karpaty and the marginal elevated structure of Pohanská Plavecký hradný vrch hills (Plavecké predhorie), both parallel with the SW-NE fault line separating Malé Karpaty and Záhorská nížina (see Maglay et al., 1999; Fig. 1). Moreover, the south-western part of Plavecké predhorie between villages of Plavecké Podhradie and Plavecký Mikuláš, slightly protruding westward into the Záhorská nížina, is dissected also by transverse NW-SE and N-S-trending faults. Therefore, this area, highly fractured by crossing faults, is appropriate for cave formation by ascending waters.

Part of meteoric waters, infiltrated in adjacent karst surfaces of Malé Karpaty, circulates downward along steep faults of the Buzkovská brázda and mixes with warmer waters rising from the depths. Mixing waters are rising along the SW-NE-trending Leitha faults, as well as N-S-trending intersecting faults, to the surface, partly along the contact of karstified Triassic carbonates and less permeable Miocene-Pleistocene sedimentary fill of the Záhorská nižina. Pliocene and Quaternary fluvial gravels, sand, and clay, as well as proluvial-deluvial and organic sediments, in a thickness of 50 to $100 \mathrm{~m}$, in some places up to $150 \mathrm{~m}$, were deposited along the subsiding eastern edge of the Vienna Basin (Vaškovská, 1971; Kováč, 2000; Fordinál et al., 2012b). They were detected by K-9 borehole north-west from the village of Plavecké Predhorie close to the PLA (Kullman, 1966, 1980). A part of rising waters can penetrate into these sedimentary formations.

The main spring of slightly warmer groundwater at the fault-limited foot of the Plavecký hradný vrch near the PLA lies at $208 \mathrm{~m}$ a.s.1. (Fig. 2C). Lake water table at the bottom of nearby Plavecká priepast is at the altitude level of springs at the foot of the Plavecký hradný vrch (Šmída, 2010). Travertine accumulation up to $550 \mathrm{~m}$ wide has been deposited at near the intersection of the Leitha faults and $\mathrm{N}-\mathrm{S}-$ striking faults, from slightly warmer and highly mineralized waters (Hanzel et al., 2001; Fig. 1). The flood plain of the Rudava River in the adjacent part of Podmalokarpatská zniženina (Sološnica Sub-Basin) lies at $185-187 \mathrm{~m}$ a.s.1. The groundwater table within the Quaternary sedimentary fill descends from the foot of the Plavecký hradný vrch to the Rudava River (Šubová et al., 1973).

The occurrence of parallel fracture-controlled structures is an important factor for hypogene speleogenesis in the Plavecký hradný vrch (unknown in other parts along the NE-SW edge of Malé Karpaty). Springs south-east from the village of Plavecké Podhradie have a shallower underground circulation manifested by lower water temperature $\left(8\right.$ to $9^{\circ} \mathrm{C}$; Hanzel et al., 1999, 2001).

\section{Multi-phased hypogene speleogenesis and its relation to landscape evolution}

Different morphologies, morphostratigraphy, as well as mineralogical and stable isotope analyses, indicate that the PLA can be a result of SAS with several expected development phases as follows:

1. The primary phreatic phase. Fault-controlled high and more or less narrow chimneys, with a phreatic morphology, developed by rising low-thermal waters during the oldest phase of speleogenesis. The upper discovery opening of the PLA, as well as the high chimney above the north-eastern edge of Kvaplová sieñ, most probably represent the oldest groundwater outlets to the surface.

2. Subsequent epiphreatic phases related to an intensified sulfuric acid dissolution. Horizontal and subhorizontal passages and halls of the PLA developed at former piezometric surfaces in four evolution levels (at 225, 220, 214, and $212 \mathrm{~m}$ a.s.1.). The origin of evolution levels was related to altitude stabilizations of karst springs at the foot of the Plavecky hradný vrch, i.e., when the base level was stable and hydrologic conditions favored the increase of water aggressivity. Hydrogen sulfide $\left(\mathrm{H}_{2} \mathrm{~S}\right)$ was released from low-thermal 
waters ascending through fissure discharge feeders. Cave levels reflected base-level changes during the multi-phased surface lowering of the adjacent part of the Záhorská nížina.

The sources of hydrogen sulfide involved in the SAS of the PLA level parts can be found in hydrocarbon reservoirs and sulphate-saline connate waters of the adjacent Vienna Basin. Hydrocarbons are hosted in deep underlying stacked carbonates, anhydrites, and overlying siliciclastic reservoirs (Ladwein, 1988; Arzmüller et al., 2006 and others). Stable sulfur isotopes signatures confirm Upper Triassic anhydrites as the main sulfur source for $\mathrm{H}_{2} \mathrm{~S}$ (Rupprecht et al., 2018). In the lower part of the Vienna Basin basement, the presence of sulphate connate waters is documented by the celestine $\left(\mathrm{SrSO}_{4}\right)$ precipitated in Upper Anisian Reifling Limestone (borehole Kuklov-3 located $2.5 \mathrm{~km}$ south-east from the village of Kúty; see Mišik, 1986). Hydrogen sulfide in deep water is mostly formed by anaerobic desulfurization bacteria growing in the presence of oxygen that is supplied by infiltration surface water (Květ, 1971). Hydrogen sulfide content in the water of the Smrdáky Spa, located at the northern edge of Vienna Basin (about $30 \mathrm{~km} \mathrm{NNE}$ from the PLA), reaches 500-700 mg/L (Gazda, 1980; Franko \& Melioris, 2000). The unusually high degree of $\mathrm{SO}_{4}{ }^{2-}$ to $\mathrm{H}_{2} \mathrm{~S}$ conversion $(97.4 \%)$, corresponded with an unusually high rate of $\mathrm{H}_{2} \mathrm{~S}$ production, is probably related to the high concentration of gaseous hydrocarbons and bitumens which provide abundant energy sources for microorganisms (Šmejkal et al., 1971). The $\mathrm{H}_{2} \mathrm{~S}$ ascends along crossing faults from underlying anhydrites (the primary sulfur source for $\mathrm{H}_{2} \mathrm{~S}$ ) into overlying Neogene formations. Sulphate waters migrate from the center of the Vienna Basin to its fault-controlled edges (Květ, 1971). Closer to the PLA, springs of water containing $\mathrm{H}_{2} \mathrm{~S}$ are located at the villages of Plavecký Mikuláš, Plavecký Peter and Prievaly, i.e., about 3.7, 6.1, and $8.2 \mathrm{~km}$ north-east, respectively. According to Gazda (1980), the source of increased sulphate content in groundwaters of proluvial sediments near the villages of Sološnica, Plavecké Podhorie and Plavecký Mikuláš is the dissolution of gypsum, finely dispersed mainly in clay shales of the melaphyre serie of Malé Karpaty.

Hypogene sulfuric acid caves originated by rising thermal water are known also on the southern and eastern edge of Vienna Basin in Austria (Plan et al., 2009; De Waele et al., 2016; Spötl et al., 2017). Thermal fluids containing $\mathrm{H}_{2} \mathrm{~S}$ originated from sulphatesaline connate waters associated with hydrocarbon reservoirs in the Vienna Basin. They ascended during compressional tectonic phases probably along deep NE-SW-trending faults parallel with the VTBF, as well as along transverse N-S-trending faults. About 25 $\mathrm{km}$ north-east from the PLA, sulphide and sulphate mineralizations of Triassic carbonates, including $\mathrm{SrSO}_{4}$ and $\mathrm{BaSO}_{4}$, were detected in the borehole DV-1 at the village of Dobrá Voda in the Brezovské Karpaty (Michalík et al., 1992).

In the area of the PLA, hydrogen sulfide has emerged from the depths into the deeper circulating meteoric waters along the VBTF, which represents an active fault system. Active sinistral movement is indicated by moderate seismic activity, focal plane solutions and recent stress measurements (Decker et al., 2005; Beidinger \& Decker, 2011). According to the estimate of the ground acceleration from the stalagmite in the nearby Plavecká priepast', the area did not experience a strong earthquake in the last several thousand years (Gribovszki et al., 2017). Cave levels, composed of passages and halls with flat corrosion floor surfaces and associated wall water-table notches, were formed by an intensified sulfuric acid dissolution at the water table during phases of stabilized erosion base on the surface in the adjacent part of Podmalokarpatská zniženina. The development of cave levels was influenced by the temporal extent of the watertable stabilization and the intensity of limestone dissolution. The largest evolution levels of the PLA are located approximately at the same altitude as Miocene sediments at the top of horst structure of the Lakšáry elevation (later mostly covered by eolian sands) in the central part of the Záhorská nížina (see Vaškovská, 1971; Kullman, 1980). Therefore, it is likely these levels were formed (or started to form) before the subsidence of the Podmalokarpatská zniženina due to the resumed tectonic activity of Vienna Basin. In the Quaternary, the tectonic reactivation of the Vienna Basin could be related to NE-SW extension of subbasins (including the Podmalokarpatská zníženina) at a releasing bend along the slow-moving sinistral strike-slip faults (Grenerczy et al., 2000; Decker et al., 2005; Beidinger \& Decker, 2011; Lee \& Wagreich, 2017), probably since $250-300$ ka (Salcher et al., 2012). Alternatively, the tectonic reactivation could be related to the change in the orientation of neotectonic extension (Fordinál et al., 2012b). Lower-lying terraces of the Rudava River (see Škvarček, 1975) were formed during the younger phases of the erosion lowering of aggradation land surface of the Podmalokarpatská zníženina.

As the cave evolution levels are situated at higher altitudes than the recent karst spring and the adjacent surface of the Podmalokarpatská zníženina, the tectonic subsidence after their origin is more intensive than the deposition of sediments on the descending surface.

\section{CONCLUSIONS}

The PLA is a multi-phased hypogene cave with several epiphreatic phases related to an intensified sulfuric acid dissolution. Numerous fissure feeders, blind chimneys, and high cupolas, as well as shallow cupolas, condensation-corrosion channels, and niches correspond with the morphology of hypogene caves. The uppermost part of limestone bedrock in the PLA was slightly altered by solutions containing deep-seated carbon. Structural and hydrogeological settings together with cave morphology indicate its origin by slightly warmer groundwaters ascending along the fault line. Meteoric waters infiltrated in the western part of the Plavecký Karst dissected by parallel faults, descend along steep discontinuities, probably mix with warmer waters rising from the depths, and 
ascend at the edge of horst mountains. Epiphreatic phases of SAS are evidenced by specific morphological features (flat corrosion bedrock floors and associated wall water-table notches), partly also by some cave deposits (pale yellow sand with gypsum and alunite, calcite popcorn rims). Four evolution levels (cave segments with fissure feeders, flat corrosion bedrock floors, and associated wall water-table notches) correspond with base-level changes during the multiphased surface lowering of the adjacent part of the Podmalokarpatská zníženina $\left(\mathrm{H}_{2} \mathrm{~S}\right.$ has emerged from the depths into the deeper circulating meteoric waters along the active VBTF).

Based on preliminary observations, some other caves in the Plavecký hradný vrch are characterized by several morphological and hydrogeological features of hypogene speleogenesis including epiphreatic phases of SAS or possibly sulfuric acid caves (e.g., Plavecká priepast' and multi-level Pec Cave). This study is a fundamental platform for future research of speleogenesis in this significance karst locality at the VBTF between Malé Karpaty and Záhorská nížina. Presented knowledge is important for a more complex view on the variability of speleogenesis in the Western Carpathians.

\section{ACKNOWLEDGEMENTS}

This work was supported by the grant of the Scientific Grant Agency of the Ministry of Education, Science, Research and Sport of the Slovak Republic and the Slovak Academy of Sciences (VEGA) No. $1 / 0146 / 19$, institutional financing of the State Nature Conservancy of the Slovak Republic, Slovak Caves Administration and the Czech Academy of Sciences, Institute of Geology (no. RVO67985831). We acknowledge the field assistance of Jaroslav Butaš, Marián Grúz, Milan Herz, Miroslav Kudla and Pavol Staník. We are grateful to Peter Magdolen and his collaborating cavers for the map of Plavecká jaskyña as well as to Branislav Šmida for consultations of some problems related to karst and cave development in the Plavecký Karst and Igor Broska for providing data on sulphide and sulphate mineralization of Triassic carbonates in the wider surrounding area of Plavecká jaskyña. Karel Žák performed analyses of gypsum leachate. Many thanks to two reviewers and the editor for their useful comments and suggestions.

\section{REFERENCES}

Arzmüller G., Buchta Š., Ralbovský E. \& Weselly G., 2006 - The Vienna Basin. In: Golonka J. \& Picha F.J. (Eds.), The Carpathians and their foreland: Geology and hydrocarbon resources. American Association of Petroleum Geologists Memoir, 84, Tulsa, p. 191-204. https://doi.org/10.1306/985608M843068

Audra P., 2008 - Hypogenic sulphidic speleogenesis. Berliner Höhlenkundliche Berichte, 26: 15-32.

Audra P., Hobléa F., Bigot J.-Y. \& Nobécourt J.-C., 2007 - The role of condensation-corrosion in thermal speleogenesis. Study of a hypogenic sulfidic cave in Aixles-Bains, France. Acta Carsologica, 36 (2): 185-194. https://doi.org/10.3986/ac.v36i2.186
Audra P., Mocochain L., Bigot J.-Y. \& Nobécourt J.-C., 2009a - Hypogene cave patterns. In: Klimchouk A.B. \& Ford D.C. (Eds.), Hypogene speleogenesis and karst hydrogeology of artesian basins. Ukrainian Institute of Speleology and Karstology, Special Paper, 1, Simferopol, p. 17-22.

Audra P., Mocochain L., Bigot J.-Y. \& Nobécourt J.-C., 2009b - Morphological indicators of speleogenesis: hypogenic speleogens. In: Klimchouk A.B. \& Ford D.C. (Eds.), Hypogene speleogenesis and karst hydrogeology of artesian basins. Ukrainian Institute of Speleology and Karstology, Special Paper, 1, Simferopol, p. 23-32.

Bakalowicz M.J., Ford D.C., Miller T.E., Palmer A.N. \& Palmer M.V., 1987 - Thermal genesis of dissolution caves in the Blach Hills, South Dakota. Geological Society of America Bulletin, 99 (6): 729-738.

https://doi.org/10.1130/0016-7606(1987)992.0.CO;2

Baňacký V. \& Sabol A., 1973 - Geologická mapa Záhorskej níżiny 1:50 000. GÚDŠ, Bratislava.

Beidinger A. \& Decker K., 2011 - 3D geometry and kinematics of the Lassee flower structure: implications for segmentation and seismotectonics of the Vienna Basin strike-slip fault, Austria. Tectonophysics, 499 (1-4): 22-40. https://doi.org/10.1016/j.tecto.2010.11.006

Bella P., 2010 - Vytváranie jaskýñ vodami vystupujúcimi pozdl̇ž okrajového zlomu Malých Karpát pri Plaveckom Podhradi - hydrogeologické podmienky a morfologické znaky. Aragonit, 15 (2): 65-70.

Bella P. \& Bosák P., 2012 - Speleogenesis along deep regional faults by ascending waters: case studies from Slovakia and Czech Republic. Acta Carsologica, 41 (23): 169-192. https://doi.org/10.3986/ac.v41i2-3.556

Bella P. \& GaáL L., 2012 - Hypogénne jaskyne na Slovensku: súčasné poznatky a zameranie výskumu. Geomorphologia Slovaca et Bohemica, 12 (1): 38-50.

Bella P. \& Gaál L., 2017 - Hypogene caves in Slovakia. In: Klimchouk A., Palmer A., De Waele J., Aurel A. \& Audra P. (Eds.), Hypogene karst regions and caves of the world. Springer, Cham, p. 299-311. https://doi.org/10.1007/978-3-319-53348-3_19

Bosák P., 2013 - Excursion - Cave „Na Turoldu“, Mikulov (24 th April 2013). Jeskyne Bradla Turold u Mikulova. In: Máčka Z., Havlíček M., Demek J. \& Kirchner K. (Eds.), Geomorfologický sborník. Ostrava - Brno, 11, p. 72-74.

Bosák P., Čadek J., Horáček I., Ložek V., Tưma S. \& Ulrych J., 1984 - Krasové jevy vrchu Turold u Mikulova. Studie Československé akademie věd, Praha, 5, 108 p.

Bottrell S.H., Crowley S. \& Self C., 2001 - Invasion of a karst aquifer by hydrothermal fluids: Evidence from stable isotopic compositions of cave mineralization. Geofluids, 1 (2): 103-121. https://doi.org/10.1046/j.1468-8123.2001.00008.x

Briestenský M., Košták B., Stemberk J., Petro L., Vozár J. \& Fojtíková L., 2010 - Active tectonic fault microdisplacement analyses: a comparison of results from surface and underground monitoring in western Slovakia. Acta Geodynamica et Geomaterialia, 7 (4): 387-397.

Briestenský M. \& Stemberk J., 2008 - Monitoring mikropohybov $v$ jaskyniach Západného Slovenska. Slovenský kras, 46 (2): 333-339.

Butaš J., 2003 - Plavecká priepast' PP-2. Spravodaj Slovenskej speleologickej spoločnosti, 34 (1): 35-38.

Caddeo G.A., Railsback R.A.L., De Waele J. \& Frau F., 2015 - Stable isotope data as constraints on models for the origin of coralloid and massive speleothems: the interplay of substrate, water supply, degassing, and evaporation. Sedimentary Geology, 318: 130-141. https://doi.org/10.1016/j.sedgeo.2014.12.008 
D’Angeli I.M., Carbone C., Nagostinis M., Parise M., Vattano M., Madonia G. \& De Waele J., 2018 - New insights on secondary minerals from Italian sulfuric acid caves. International Journal of Speleology, 47 (3): $271-$ 291. https://doi.org/10.5038/1827-806X.47.3.2175

Decker K., 1996 - Miocene tectonics at the AlpineCarpathian junction and the evolution of the Vienna basin. Mitteilungen der Gesellschaft der Geologie- und Bergbaustudenten in Österreich, 41: 33-44.

Decker K., Peresson H. \& Hinsch R., 2005 - Active tectonics and Quaternary basin formation along the Vienna Basin Transform fault. Quaternary Science Reviews, 24 (3-4): 305-320. https://doi.org/10.1016/j.quascirev.2004.04.012

Deines P. \& Gold D.P., 1973 - The isotopic composition of carbonite and kimberlite carbonates and their bearing on the isotopic composition of deep seated carbon. Geochimica et Cosmochimica Acta, 37 (7): 1709-1733. https://doi.org/10.1016/0016-7037(73)90158-0

De Waele J., Audra P., Madonia G., Vattano M., Plan L., D’Angeli I.M., Bigot J.-Y. \& Nobécourt J.-V., 2016 - Sulfuric acid speleogenesis (SAS) close to the water table: Examples from southern France, Austria, and Sicily. Geomorphology, 253: 452-467.

https://doi.org/10.1016/j.geomorph.2015.10.019

Droppa A., 1958 - Plavecká jaskyña. Československý kras, 8-9: 120-123.

Droppa A., 1973 - Prehlad preskúmaných jaskýn̆ na Slovensku. Slovenský kras, 11: 111-157.

Dublyansky Y. \& Spötl C., 2009 - Identifying paleo waterrock interaction during hydrothermal karstification: a stable isotope approach. In: Klimchouk A. \& Ford D. (Eds.), Hypogene speleogenesis and karst hydrogeology of artesian basins. Special Paper, Ukrainian Institute of Speleology and Karstology, Kiev, 1, p. 45-49.

Dublyansky Y.V., Klimchouk A.B., Spötl C., Timokhina E.I. \& Amelichev G.N., 2014 - Isotope wallrock alteration associated with hypogene karst of the Crimean Piedmont, Ukraine. Chemical Geology, 377: 31-44. https://doi.org/ 10.1016/j.chemgeo.2014.04.003

Egemeier S.J., 1981 - Cavern development by thermal waters. Bulletin of the National Speleological Society, 43 (2): 31-51.

Fairchild I.J. \& Baker A., 2012 - Speleothem science: From process to past environments. Wiley-Blackwell, $450 \mathrm{p}$. https://doi.org/10.1002/9781444361094

Fodor L., 1995 - From transpression to transtension: Oligocene-Miocene structural evolution of Vienna basin and the East Alpine-Western Carpathian junction. Tectonophysics, 242: 151-182.

https://doi.org/10.1016/0040-1951(94)00158-6

Fordinál K., Maglay J., Elečko M., Nagy A., Moravcová M., Vlačiky M., Kučera M., Polák M., Plašienka D., Filo I., Olšavský M., Buček S., Havrila M., Kohút M., Bezák V. \& Németh Z., 2012a - Geologická mapa Záhorskej nižiny $v$ mierke 1:50 000. MŽP SR, Štátny geologický ústav Dionýza Štúra, Bratislava.

Fordinál K., Maglay J., Elečko M., Nagy A., Moravcová M., Vlačiky M., Kohút M., Németh Z., Bezák V., Polák M., Plašienka D., Olšavský M., Buček S., Havrila M., Hók J., Pešková I., Kucharič L., Kubeš P., Malik M., Baláž P., Liščák P., Madarás J., Šefčík P., Baráth I., Boorová D., Uher P., Zlinská A. \& Žecová K., 2012b Vysvetlivky ku geologickej mape Záhorskej nižiny 1:50 000. ŠGÚDS̆, Bratislava, 232 p.

Franko O. \& Melioris L., 2000 - Minerálne a termálne vody Slovenska - vznik a rozširenie. Podzemná voda, 6 (1): 5-28.
Galdenzi S., 2012 - Corrosion of limestone tablets in sulfidic ground-water: measurements and speleogenetic implications. International Journal of Speleology, 41 (2): 149-159.

https://doi.org/10.5038/1827-806X.41.2.3

Galdenzi S. \& Maruoka T., 2003 - Gypsum deposits in the Frasassi Caves, central Italy. Journal of Cave and Karst Studies, 65 (2): 111-125.

Galdenzi S. \& Maruoka T., 2019 - Sulfuric acid caves in Calabria (South Italy): Cave morphology and sulfate deposits. Geomorphology, 328: 211-221. https://doi.org/10.1016/j.geomorph.2018.12.014

Gazda S., 1980 - Hydrogeochemické pomery Záhorskej niżiny. Západné Karpaty, séria hydrogeológia a inžinierska geológia, 2: 27-192.

Gonzalez L.A. \& Lohmann K.C., 1988 - Controls on mineralogy and composition of spelean carbonates, Carlsbad Caverns, New Mexico. In: James N.P. \& Choquette P.W. (Eds.), Paleokarst. Springer, New York, p. 81-101.

https://doi.org/10.1007/978-1-4612-3748-8_4

Grenerczy G., Kenyeres A. \& Fejes I., 2000 - Present crustal movement and strain distribution in Central Europe inferred from GPS measurements. Journal of Geophysical Research, 105 (B9): 21835-21846. https://doi.org/10.1029/2000JB900127

Gribovszki K., Kovács K., Mónus P., Bokelmann G., Konečný P., Lednická M., Moseley G., Spötl C., Edwards R.L., Bednárik M., Brimich L. \& Tóth L., 2017 - Estimating the upper limit of prehistoric peak ground acceleration using an in situ, intact and vulnerable stalagmite from Plavecká priepast' cave (Detrekőizsomboly), Little Carpathians, Slovakia - first results. Journal of Seismology, 21 (5): 1111-1130. https://doi.org/10.1007/s10950-017-9655-3

Grúz M., 2019 - Občianske združenie Jaskyniari Plavecké Podhradie. Spravodaj Slovenskej speleologickej spoločnosti, 50 (1): 59-61.

Hanzel V., Vrana K. \& Kúšiková S., 2001 - Hydrogeologická mapa Pezinských Karpát v mierke 1:50 000. In: Malik P. (Ed.), Hydrogeologické a hydrogeochemické mapy $v$ mierke 1:50 000, regióny: južná čast'Záhorskej (Borskej) nižiny, Pezinské Karpaty, SV čast’ Podunajskej nížiny, východná čast' Vel'kej Fatry, severná čast' Spišskogemerského rudohoria, Lubovnianksa urchovina a Pieniny, Čierna hora. MŽP SR Bratislava, ŠGÚDŠ Bratislava, CD-ROM.

Hanzel V., Vrana K., Švasta J., Kohút M., Nagy A., Maglay J., Bujnovský A. \& Malík P., 1999 - Hydrogeologická a hydrogeochemická mapa Pezinských Karpát v mierke 1:50 000. Manuscript, GS SR Bratislava, $179 \mathrm{p}$.

Herz M. \& Velšmid M., 2018 - Postup v Plaveckej jaskyni- „Pjetka“. Spravodaj Slovenskej Speleologickej Spoločnosti, 49 (4): 35-37.

Hill C.A., 1987 - Geology of Carlsbad Cavern and other caves in the Guadalupe Mountains, New Mexico and Texas. New Mexico Bureau of Mines and Mineral Resources Bulletin, 117, 150 p.

Hill C.A., 1990 - Sulfuric acid speleogenesis of Carlsbad Cavern and its relationship to hydrocarbons, Delaware Basin, New Mexico and Texas. The American Association of Petroleum Geologists Bulletin, 74 (11): 1685-1694. https://doi.org/10.1306/0C9B2565-1710-11D7$\underline{8645000102 \mathrm{C} 1865 \mathrm{D}}$

Hochmuth Z., 2008 - Krasové územia a jaskyne Slovenska. Geographia Cassoviencis, 2 (2), 210 p.

Hók J., Littva J., Šujan M., Šamajová L., Šujan M. \& Šipka F., 2018 - Geological structure of the Dobrá Voda seismoactive area (western Slovakia). Acta Geologica Slovaca, 10 (2): 143-150. 
Holko L., Dóša M., Michalko J., Kostka Z. \& Šanda M., 2012 - Isotopes of oxygen-18 and deuterium in precipitation in Slovakia. Journal of Hydrology and Hydromechanics, 60 (4): 265-276.

https://doi.org/10.2478/V10098-012-0023-2

Hubek M. \& Magdolen P., 2008 - Plavecká jaskyña - nové objavy a nová mapa. Spravodaj Slovenskej speleologickej spoločnosti, 39 (1): 58-61.

Jones D.S., Polerecky L., Galdenzi S., Dempsey B.A. \& Macalady J.L., 2015 - Fate of sulfide in the Frasassi cave system and implications for sulfuric acid speleogenesis. Chemical Geology, 410: 21-27.

https://doi.org/10.1016/j.chemgeo.2015.06.002

Košel V., 2005 - Ktorá je najteplejšia? Spravodaj Slovenskej speleologickej spoločnosti, 36 (4): 29-30.

Kováč M., 2000 - Geodynamický, paleogeografický a štruktúrny vývoj karpatsko-panónskeho regiónu $v$ miocéne: Nový pohlad na neogénne panvy Slovenska. Veda, Bratislava, 204 p.

Kováč M., Baráth I., Harzhauser M., Hlavatý I. \& Hudáčková N., 2004 - Miocene depositional systems and sequence stratigraphy of the Vienna Basin. Courier Forschungsinstitut Senckenberg, 246: 187-212.

Kováč M., Baráth I. \& Nagymarosy A., 1997 - The Miocene collapse of the Alpine-Carpathian-Pannonian junction: an overview. Acta Geologica Hungarica, 40 (3): 241-264.

Kullman E., 1966 - Základný hydrogeologický výskum kvartéru Záhorskej niżiny - záverečná správa. Manuscript, Geofond, GÚDŠ, Bratislava, 91 suppl, 169 p.

Kullman E., 1980 - Hydrogeológia kvartéru a najvyšších častí neogénu Záhorskej nížiny. Západné Karpaty, séria hydrogeológia a inžinierska geológia, 2: 7-125.

Kullman E., 1990 - Krasovo-puklinové vody. GÚDŠ, Bratislava, 184 p.

Květ R., 1971-ZurGenese derSchwefeiwasserstoffwässer von Bad Smrdáky. Časopis pro mineralogii a geologii, 16 (2): 133-145.

Ladwein H.W., 1988 - Organic geochemistry of Vienna Basin: Model for hydrocarbon generation in overthrust belts. American Association of Petroleum Geologists, Bulletin, 72 (5): 586-599.

https://doi.org/10.1306/703C8ED4-1707-11D78645000102C1865D

Lalkovič M., 2010 - Plavecká jaskyña-prvá sprístupnená jaskyn̆a na Slovensku. Aragonit, 15 (1): 19-28.

Lankreijer A., Kováč M., Cloetingh S., Pitoňák P., Hlôška M. \& Biermann C., 1995 - Quantitative subsidence analysis and forward modelling of the Vienna and Danube basins: thin-skinned versus thick-skinned extension. Tectonophysics, 252: 433-451. https://doi.org/10.1016/0040-1951(95)00099-2

Lee E.Y. \& Wagreich M., 2017 - Polyphase tectonic subsidence evolution of the Vienna Basin inferred from quantitative subsidence analysis of the northern and central parts. International Journal of Earth Sciences (Geologische Rundschau), 106 (2): 687-705. https://doi.org/10.1007/s00531-016-1329-9

Lehotská B. \& Lehotský R., 2010 - Zhrnutie poznatkov o zimovani netopierov $v$ Plaveckej jaskyni. Ochrana prírody, 26: 71-74.

Liška M., 1976 - Geomorfologické pomery Plaveckého krasu. Slovenský kras, 14: 31-59.

Maglay J., Halouzka R., Baňacký V., Pristaš J., Janočko J. \& Hók J., 1999 - Neotektonická mapa Slovenska 1:500 000. GS SR, Bratislava.

Mahel M., 1986 - Geologická stavba československých Karpát, 1, Paleoalpinske jednotky. Veda, Bratislava, 509 p.

Mahel' M., 1987 - The Malé Karpaty Mts. - constituent of the transitional segment between the Carpathians and Alps; important tectonic window of the Alpides. Mineralia Slovaca, 19 (1): 1-27.

Mahel M. \& Cambel B., 1972 - Geologická mapa Malých Karpát, 1:50 000. GÚDŠ, Bratislava.

Marko F. \& Jureňa V., 1999 - Zlomová tektonika východného okraja Viedenskej panvy a hrastu Malých Karpát. Mineralia Slovaca, 31 (5-6): 513-524.

Michalík J., Broska I., Francu J., Jendrejáková O., Kochanová M., Lintnerová O., Masaryk P., Papšová J., Planderová E., Šucha V. \& Zatkalíková V., 1992 - Štruktúrny vrt Dobrá Voda DV-1 (1140,8 m, Konča skaliek) v Brezouských Karpatoch. Regionálna geológia Západných Karpát, 27, GƯDŠ, Bratislava, 140 p.

Mišik M., 1986 - Fluorit a celestin z karbonatických hornín triasu $z$ podložia Viedenskej panvy. Mineralia Slovaca, 18 (3): 259-266.

Mitter P., 1983 - Geomorfologická rajonizácia krasu Malých Karpát. Slovenský kras, 21: 3-34.

Palmer A.N., 2013 - Sulfuric acid caves: Morphology and evolution. In: Shroder J. \& Frumkin A. (Eds.), Treatise on Geomorphology. Academic Press, San Diego, p. 241-257. https://doi.org/10.1016/B978-0-12-374739$\underline{6.00133-0}$

Palmer A.N., 2016 - Sulfuric acid vs. epigenic carbonic acid in cave origin and morphology. In: Chavez T. \& Reehling P. (Eds.), Proceedings of DeepKarst 2016: Origins, resources, and management of hypogene karst. NCKRI Symposium 6, National Cave and Karst Research Institute, Carlsbad, New Mexico, p. 7-15.

Palmer A.N. \& Hill C.A., 2005 - Sulfuric acid caves. In: Culvier D.C. \& White W.B. (Eds.), Encyclopedia of caves. Elsevier Academic Press, Burlington, p. 573-581.

Palmer M.V. \& Palmer A.N., 2012 - Petrographic and isotopic evidence for late-stage processes in sulfuric acid caves of the Guadalupe Mountains, New Mexico, USA. International Journal of Speleology, 41 (2): 231-250. https://doi.org/10.5038/1827-806X.41.2.10

Pavuza R. \& Plan L., 2008 - Hydrothermalkarst im Breich des Südlichen Wiener Beckens. In: Schaudy R. \& Withalm G. (Eds.), Höhle und Mensch - Beiträge zur Karst- und Höhlenkunde mit Schwerpunkt Baden bei Wien. Speldok, Wien, 18, p. 1-17.

Plan L., Pavuza R. \& Seemann R., 2006 - Der Nasse Achacht bei Mannersdorf am Leithagebirge, NÖ (2911/21) - eine thermal beeninflusste Höhle am Ostrand des Wiener Beckens. Die Höhle, 57 (1-4): 30-46.

Plan L., Spötl C., Pavuza R. \& Dublyansky Y., 2009 Hypogene caves in Austria. In: Klimchouk A.B. \& Ford D.C. (Eds.), Hypogene speleogenesis and karst hydrogeology of artesian basins. Ukrainian Institute of Speleology and Karstology, Special Paper, 1, Simferopol, p. 121-127.

Plan L., Tschegg C., De Waele J. \& Spötl C., 2012 Corrosion morphology and cave wall alteration in an Alpine sulfuric acid cave (Kraushöhle, Austria). Geomorphology, 169-170: 45-54.

https://doi.org/10.1016/j.geomorph.2012.04.006

Plašienka D., Michalík J., Kováč M., Gross P. \& Putiš M., 1991 - Paleotectonic evolution of the Male Karpaty Mts - An overview. Geologica Carpathica, 42 (4): 195-208.

Polák M., Plašienka D., Kohút M., Putiš M., Bezák V., Filo I., Olšavský M., Havrila M., Buček S., Maglay J., Elečko M., Fordinál K., Nagy A., Hraško L., Németh Z., Ivanička J. \& Broska I., 2011 - Geologická mapa regiónu Malých Karpát v mierke 1:50 000. MŽP SR, Štátny geologický ústav Dionýza Štúra, Bratislava.

Polák M., Plašienka D., Kohút M., Putiš M., Bezák V., Maglay J., Olšavský M., Havrila M., Buček S., Elečko M., Fordinál K., Nagy A., Hraško L., Németh Z., Malík P., 
Liščák P., Madarás J., Slavkay M., Kubeš P., Kucharič L., Boorová D., Zlínska A., Síráňová Z. \& Žecová K., 2012 - Vysvetlivky ku geologickej mape regiónu Malé Karpaty v mierke 1:50 000. MŽP SR, Štátny geologický ústav Dionýza Štúra, Bratislava, 309 p.

Polyak V.J. \& Güven N., 1996 - Alunite, natroalunite, and hydrated halloysite in Carlsbad Cavern and Lechuguilla Cave, New Mexico. Clays and Clay Minerals, 44 (6): 843850. https://doi.org/10.1346/CCMN.1996.0440616

Polyak V.J. \& Provencio P., 1998 - Hydrobasaluminite and aluminite in caves of the Guadalupe Mountains, New Mexico. Journal of Cave and Karst Studies, 60 (1): 51-57.

Polyak V.J. \& Provencio P., 2001 - By-product materials related to $\mathrm{H}_{2} \mathrm{~S}-\mathrm{H}_{2} \mathrm{SO}_{4}$ influenced speleogenesis of Carlsbad, Lechuguilla, and other caves of the Guadalupe Mountains, New Mexico. Journal of Caves and Karst Science, 63 (1): 23-32.

Rodriguez-Clemente R. \& Hidalgo-Lopez A., 1985 - Physical conditions in alunite precipitation as a secondary mineral. In: Drever J.I. (Ed.), The chemistry of weathering. Nato ASI Series, 149, Springer, Dordrecht, p. 121-141.

https://doi.org/10.1007/978-94-009-5333-8_8

Röller K. \& Trepmann C.A., 2003 - Stereo32. 1.0.1. Institut für Geologie, Ruhr University Bochum, Bochum.

Royden L.H., 1985 - The Vienna Basin: A thin skinned pull-apart basin. In: Biddle K.T. \& Christie-Blick N. (Eds.), Strike-slip deformation, basin formation and sedimentation. The Society of Economic Paleontologists and Mineralogists, Special Publication, 37, Tulsa, p. 319-339.

https://doi.org/10.2110/pec.85.37.0303

Rupprecht B.J., Sachsenhofer R.F., Zach C., Bechtel A., Gratzer R. \& Kucher F., 2018 - Oil and gas in the Vienna Basin: hydrocarbon generation and alteration in a classical hydrocarbon province. Petroleum Geoscience, 25 (1): 3-29. https://doi.org/10.1144/petgeo2017-056

Salcher B.C, Meurers B., Smit J., Decker K., Hölzel M. \& Wagreich M., 2012 - Strike-slip tectonics and Quaternary basin formation along the Vienna Basin fault system inferred from Bouguer gravity derivatives. Tectonics, 31 (3): TC3004. https://doi.org/10.1029/2011TC002979

Sarbu S.M. \& Lascu C., 1997 - Condensation corrosion in Movile cave, Romania. Journal of Cave Karst Studies, 59 (3): 99-102.

Škvarček A., 1975 - Príspevok ku kvartérnemu vývinu doliny Rudavy na Záhorskej nížine. Geografický časopis, 27 (4): 364-371.

Šmejkal V., Michalíček, M. \& Krouse H.R., 1971 - Sulphur isotope fractionation in some springs of the Carpathian mountain system in Czechoslovakia. Časopis pro mineralogii a geologii, 16 (3): 275-283.

Šmída B., 2010 - Geomorfológia a genéza Plaveckého krasu ako modelového územia tzv. kontaktného krasu Západných Karpát s nižšou energiou reliéfotvorby. PhD Thesis, Faculty of Natural Sciences, Comenius University, Bratislava, $221 \mathrm{p}$.

Spötl C., Dublyansky Y., Meyer M. \& Mangini A., 2009 - Identifying low-temperature hydrothermal karst and palaeowaters using stable isotopes: a case study from an alpine cave, Entrische Kirche, Austria. International Journal of Earth Sciences, 98 (3): 665-676. https://doi.org/10.1007/s00531-007-0263-2

Spötl C., Plan L. \& Dublyanski Y., 2017 - Hypogene karst in Austria. In: Klimchouk A., Palmer A., De Waele J., Aurel A. \& Audra P. (Eds.), Hypogene karst regions and caves of the world. Springer, Cham, p. 113-126. https://doi.org/10.1007/978-3-319-53348-3_6

Šubová A., Holéczyová Z., Sabol A., Banský V., Némethy P., Gazda S., Motlíková O., Fukna M., Bittner D., Tomlain J., Peterka V., Žák B., Machmerová E. \& Oláhová A., 1973 - Záhorská nižiny II - Sološnická a Zohorská nádrž podzemných vôd - pitné vody, vyhladávací hydrogeologický prieskum. Manuscript, Geofond, GÚDŠ, Bratislava, 132 p.

Temovski M., Audra P., Mihevc A., Spangenberg J., Polyak V., McIntosh W. \& Bigot J., 2013 - Hypogenic origin of Provalata Cave, Republic of Macedonia: a distinct case of successive thermal carbonic and sulfuric acid speleogenesis. International Journal of Speleology, 42 (3): 235-246. https://doi.org/10.5038/1827-806X.42.3.7

Tencer J., 1991 - Nové poznatky o Plaveckom krase. Jaskyniar, p. 3-9.

Tencer J., 2019 - Tabulka najdlhšich jaskýn̆ na Slovensku (stav k 31. 3. 2019). Spravodaj Slovenskej speleologickej spoločnosti, 50 (1): 105.

Thrailkill J., 1971 - Carbonate deposition in Carlsbad Caverns. Journal of Geology, 79 (6): 683-695. https://doi.org/10.1086/627698

Vaškovská E., 1971 - Litologicko-faciálna charakteristika genetických typov kvartérnych sedimentov Záhorskej nížiny. Geologické práce, Správy, 55: 5-42.

Vattano M., Audra P., Benvenuto F., Bigot J.-Y., De Waele J., Galli E., Madonia G. \& Nobécourt J.-C., 2013 - Hypogenic caves of Sicily (Southern Italy). In: Filippi M. \& Bosák P. (Eds.), Proceedings of the $16^{\text {th }}$ International Congress of Speleology, Brno 19-27 July 2013, 3, p. 144-149.

Zupan Hajna N., 2003 - Incomplete solution: Weathering of cave walls and the production, transport and depositions of carbonate fines. Carsologica, Založba ZRC, Postojna - Ljubljana, 3, 167 p. 